KS. JAN KRAJCZYŃSKI

Prawo Kanoniczne

62(2019) $\mathrm{nr} 1$

DOI:10.21697/pk.2018.62.1.06

Wydział Prawa Kanonicznego

Uniwersytetu Kardynała Stefana Wyszyńskiego w Warszawie

ORCID: 0000-0001-9170-4449

\title{
KOMPETENCJE SĘDZIEGO INSTRUKTORA W PROCESIE SKRÓCONYM
}

Treść: Wstęp. - 1. Instructoris munus, czyli urząd sędziego instruktora. -2 . Szczególne obowiązki i prawa instruktora w sprawach rozpoznawanych w procesie skróconym. - 2.1. Bezzwłoczne dokonanie instrukcji sprawy. - 2.2. Zebranie dowodów w sprawie, o ile to możliwe podczas jednego posiedzenia sądu. - 2.3. Uzupełnienie instrukcji, jeśli podczas posiedzenia sądu, o jakim jest mowa w kan. 1685 i 1686 MIDI, nie zebrano wszystkich dowodów. - 2.4. Ogłoszenie akt i dyskusja sprawy. - 2.5. Przekazanie akt sprawy i konsultacja $\mathrm{z}$ biskupem diecezjalnym. - 3. Zasady prawa, jakie powinien uszanować instruktor w procesie skróconym. - 3.1. Sam biskup jest sędzią w procesie skróconym. - 3.2. Sprawa o orzeczenie nieważności małżeństwa nie może być rozpoznawana w drodze ustnego procesu spornego lub sumarycznego. - 3.3. Postępowanie nie tylko na wniosek stron, ale także $z$ urzędu. - 3.4. Troska o zachowanie formalnych wymogów dotyczących instrukcji sprawy. - 3.5. Posługa w duchu zasad prawa: favor matrimonii i favor indissolubilitatis, nie zaś favor libertatis lub favor personae. - Zakończenie.

\section{Wstęp}

W motu proprio papieża Franciszka „Mitis Iudex Dominus Iesus” [dalej: MIDI] dokonano reformy niektórych kanonów Kodeksu prawa kanonicznego ${ }^{1}$, dotyczących spraw o nieważność małżeństwa.

\footnotetext{
${ }^{1}$ Codex Iuris Canonici. Auctoritate Ioannis Pauli pp. II promulgatus, AAS 75 (1983) s. 1-317. Kodeks Prawa Kanonicznego. Przekład polski zatwierdzony przez
} 
Przewidziano mianowicie możliwość przeprowadzenia tego postępowania sądowego w trybie skróconym² ${ }^{2}$ gdzie sędzią jest sam biskup

Konferencję Episkopatu, Pallottinum 1984 [dalej: KPK].

${ }^{2}$ Należy pamiętać, że już KPK i Codex Canonum Ecclesiarum Orientalium. Auctoritate Ioannis Pauli pp. II promulgatus, AAS 82 (1990) s. 1033-363 [dalej: KKKW], przewidywano wiele ułatwień o charakterze proceduralnym, dzięki którym postępowanie sądowe o orzeczenie nieważności małżeństwa mogło ulec przyspieszeniu. Pośród takich korzystnych rozwiązań prawnych należy wymienić następujące: 1) ustanowienie sędziego jednoosobowego (zob. kan. $1425 \$ 4$ KPK, kan. $1084 \$ 3$ KKKW); 2) powierzenie urzędu sędziego kościelnego kompetentnemu wiernemu świeckiemu (zob. kan. $1421 \S 2 \mathrm{KPK}$, kan. $1087 \$ 2 \mathrm{KKKW}$ ); 3) ustanowienie przy każdym trybunale kościelnym urzędu, który gwarantuje uzyskanie natychmiastowej i bezpłatnej porady oraz informacji w zakresie procedury kanonicznej [zob. Pontificium Consilium de Legum Textibus, Instructio servanda a tribunalibus dioecesanis et interdioecesanis in pertractandis causis nullitatis matrimonii Dignitas Connubii, (25 I 2005), Communicationes 37 (2005) s. 11-92 \{dalej: DC\}, art. $113 \$ 1$; 4) powołanie dla przeprowadzenia postępowania dowodowego audytora spośród sędziów trybunału lub osób zatwierdzonych przez biskupa diecezjalnego do tej funkcji (zob. kan. $1428 \mathrm{KPK}$, kan. $1093 \mathrm{KKKW}$ ); 5) ustanowienie trybunału międzydiecezjalnego (zob. kan. $1423 \$ 1-2,1439 \$ 1-3$, $1445 \$ 3$ nr 3 KPK, kan. 1067$1068 \mathrm{KKKW})$; 6) przedłożenie przez same strony, na podstawie treści skargi powodowej, formuły wątpliwości wraz z pierwszym wezwaniem sądowym (zob. art. 127 $\$ 2$ DC); 7) bezzwłoczne potwierdzenie $w$ formie dekretu trybunału apelacyjnego wyroku pozytywnego, wydanego na niższym stopniu sądu (zob. kan. $1682 \$ 2 \mathrm{KPK}$ ); 8) uzyskanie dyspensy a duplice decisione conformi (zob. Benedictus XVI, Litterae apostolicae motu proprio datae Antiqua ordinatione Quibus Supremi Tribunalis Signaturae Apostolicae lex propria promulgatur, art. 115); 9) uzyskanie innego aktu łaski Sygnatury Apostolskiej w zakresie administrowania sprawiedliwością, typu: dyspensa od zachowania prawa procesowego w poszczególnym przypadku, commissio pontificia, prorogatio competentiae (zob. kan. $1445 \$ 3$ KPK; IoAnNes PaUlus II, Constitutio apostolica Pastor Bonus, art. 124; Benedictus XVI, Litterae apostolicae motu proprio datae Antiqua ordinatione Quibus Supremi Tribunalis Signaturae Apostolicae lex propria promulgatur, art. 35). Szerzej nt. wymienionych form przyspieszenia postępowania sądowego o stwierdzenie nieważności małżeństwa zob.: G. ERLEBACH, Gli aspetti procedurali del „processus brevior" nella giurisprudenza rotale, Periodica de Re Canonica 88 (1999) s. 725-753; G. P. MonTini, La prassi delle dispense da leggi processuali del Supremo Tribunale della Segnatura Apostolica (art. 124, n. 2, 2 ${ }^{\text {a }}$ parte, Cost. Ap. „Pastor bonus”), Periodica de Re Canonica 94 (2005) s. 43-117; tenże, L'appello in una causa di nullità matrimoniale, Quaderni 
diecezjalny33. W przypadku, kiedy wikariusz sądowy - w myśl kan. $1676 \$ 2$ MIDI - zdecyduje, że sprawa o orzeczenie nieważności małżeństwa ma być rozpoznana w procesie skróconym, ustawodawca postanawia o udziale $\mathrm{w}$ takim postępowaniu sędziego instruktora.

Szczere pragnienie rozstrzygania spraw małżeńskich zgodnie z zasadami prawa kanonicznego domaga się dogłębnej analizy obowiązujących przepisów, w których określono specyficzne uprawnienia

di Diritto Ecclesiale 22 (2009) s. 318-334; P. Malecha, Commissioni pontificie e proroghe di competenza nelle cause di nullità del matrimonio alla luce della recente giurisprudenza della Segnatura Apostolica, Ius Ecclesiae 23 (2011) s. 205-251; tenże, Le dispense dalle leggi processuali alla luce di recenti documenti della Segnatura Apostolica. Alcune considerazioni pratiche, Ius Ecclesiae 25 (2013) s. 239-260; tenże, Gwarancja sprawiedliwości oraz reforma procesu małżńskiego widziana przez pryzmat konieczności jego przyśpieszenia i ułatwienia wiernym kontaktu z trybunałem; przygotowanie pracowników i odpowiedzialność biskupa, Roczniki Nauk Prawnych 25 (2015) nr 4, s. 154-156; H. MOREAU, La sentence unique exécutoire en faveur de la nullité et les modalités d'appel à la lumière du motu proprio Mitis Iudex Dominus Iesus, Revue de Droit Canonique 67 (2017) 1, s. 140-149.

Zdaniem wielu wymienione wyżej rozwiązania prawne, służące usprawnieniu i przyspieszeniu postępowania w sprawach o orzeczenie nieważności małżeństwa, były niewystarczające. Stąd zgłaszano postulaty zreformowania postępowania w sprawach o stwierdzenie nieważności małżeństwa. Wśród najczęściej przedkładanych wniosków de lege ferenda były te dotyczące wprowadzenia w sprawach o orzeczenie nieważności małżeństwa w przypadkach szczególnie oczywistych procesu sumarycznego $\mathrm{z}$ ograniczoną do minimum procedurą sądową lub procesu administracyjnego przed biskupem. Wspomniane postulaty zostały też przywołane w trakcie obrad nadzwyczajnego zgromadzenia generalnego synodu biskupów poświęconego duszpasterstwu rodziny i znalazły swój wyraz w oficjalnej Relacji synodalnej (zob. Sinodo dei Vescovi. III Assemblea Generale Straordinaria „Le sfide pastorali sulla famiglia nel contesto dell'evangelizzazione”. Relatio Synodi, n. 48). Por. PH. Toxé, La réforme des procès en nullité de mariage selon le motu proprio Mitis Iudex Dominus Iesus, L'Année Canonique 56 (2014-2015) s. 112 ; L. De Ruschi, El processus brevior del motu proprio Mitis Iudex Dominus Iesus. Una interpretación doctrinal, Anuario Argentino de Derecho Canónico 22 (2016) s. 201-202.

${ }^{3}$ Lettera apostolica Mitis Iudex Dominus Iesus data Motu Proprio dal Santo Padre Francesco sulla riforma del processo canonico per le cause di dichiarazione di nullità del matrimonio nel Codice di Diritto Canonico, (8 IX 2015), IV, http:// w2.vatican.va/content/franesco/it/motu_proprio/documents [10-09-2015]. 
i obowiązki sędziego instruktora ${ }^{4} \mathrm{w}$ tym nadzwyczajnym procesie ${ }^{5}$. Niniejsze studium stanowi próbę zdefiniowania kompetencji sędziego instruktora. Wymieniony cel autor opracowania usiłuje osiągnąć z pomocą metody dogmatyczno-prawnej.

Ustalenie wspomnianych szczególnych kompetencji sędziego instruktora w procesie skróconym posiada istotne znaczenie społeczne i prawne. Poznanie tych zupełnie nowych uprawnień i obowiązków może w istotnej mierze przysłużyć się zachowaniu sprawiedliwości kanonicznej oraz ochronie małżeństwa i rodziny.

\section{Instructoris munus, czyli urząd sędziego instruktora}

Urząd sędziego instruktora w procesach kościelnych jest znany od wieków. W gestii tego sędziego delegowanego spoczywa instrukcja

\footnotetext{
${ }^{4}$ Jest tu mowa przede wszystkim o następujących aktach normatywnych: KPK; DC; MIDI. Należy tu nadmienić, że zasady prawa zawarte w DC, jak zaznaczono w tytule wspomnianej instrukcji, „należy zachowywać w sądach diecezjalnych i międzydiecezjalnych w prowadzeniu [wszystkich - J.K.] spraw o nieważność małżeństwa". Podkreślono to również w ostatnim zdaniu obszernego wprowadzenia do tego dokumentu. Stwierdzono tam wyraźnie: „Dlatego też w prowadzeniu spraw dotyczących nieważności małżeństwa w sądach diecezjalnych i międzydiecezjalnych, mają być przestrzegane następujące normy: [...]”. Innymi słowy, przepisy zawarte w DC należy stosować w sądach Kościoła łacińskiego we wszystkich sprawach o orzeczenie nieważności małżeństwa, tak tych rozpoznawanych w procesach zwyczajnych, jak tych, które rozstrzyga się w trybie procesu opartego na dokumentach (por. DC, art. 295-299) lub procesu skróconego, nieznanego w dniu jej publikacji. Owszem, w art. $7 \$ 1-2$ DC zastrzeżono: „Instrukcja ta zajmuje się tylko procesem o orzeczenie nieważności małżeństwa, nie zaś procesami do uzyskania rozwiązania węzła małżeńskiego (por. kan. $1400 \$ 1$, n. 1; 1697-1706). Dlatego też, w tym również co dotyczy terminologii, trzeba mieć wyraźnie na uwadze różnicę między orzeczeniem nieważności a rozwiązaniem węzła".

${ }^{5}$ Jako taki właśnie, tj. processo extraordinario, kwalifikuje orzekanie w sprawach o nieważność małżeństwa w procesie skróconym Manuel Jesús Arroba Conde. Zob. tenże, El proceso más breve ante el obispo, w: Reforma de los procesos de nulidad y otras novedades legislativas de Derecho Canónico y Eclesiástico del Estado. Actas de las XXXVI Jornadas de Actualidad Canónica, organizadas por la Asociación Española de Canonistas y celebradas en Madrid, los días 30 y 31 de marzo y 1 de abril de 2016, L. Ruano Espina, C. Guzmán Pérez (Eds.), Madrid 2017, s. 253-254.
} 
sprawy w niektórych procesach małżeńskich i spornych ${ }^{6}$. Co istotne, w przypadku procesów małżeńskich, ustawodawca - tak w kodeksie z 1917, jak w tym z 1983 roku - na określenie sędziego, w którego gestii są czynności z zakresu postępowania dowodowego, używa następujących dwóch pojęć: „audytor” (łac. auditor), kiedy dopuszcza jego wyznaczenie dla dokonania instrukcji sprawy w procesie zwyczajnym o orzeczenie nieważności małżeństwa ${ }^{7}$ lub nakazuje jego ustanowienie, kiedy ów proces prowadzi sędzia jednoosobowy ${ }^{8}$, oraz „instruktor” (łac. instructor), którego poleca wyznaczyć dla przeprowadzenia instrukcji w procesie skróconym o stwierdzenie nieważności małżeństwa i w procesie do dyspensy od małżeństwa zawartego a niedopełnionego ${ }^{9}$.

Zróżnicowanie filologiczne dokonane przez najwyższego ustawodawcę, kiedy to na określenie osoby, której zleca się specyficzne zadania z zakresu instrukcji sprawy, posługuje się on dwoma różnymi pojęciami: „audytor” i „instruktor”, posiada głębokie uzasadnienie teologiczne. Jakkolwiek jeden i drugi sędzia działa na mocy zlecenia i z zasady pełni jedynie funkcje pomocnicze, to jest dochodzeniowe, rozpoznawcze i sprawdzające, ich udział w itinere procesu istotnie się różni ${ }^{10}$. O ile bowiem sędzia audytor, jeśli nie jest członkiem

\footnotetext{
${ }^{6}$ Por. kan. $1590 \$ 2$ KPK.

${ }^{7}$ Zob. kan. 1428 \$ 1-3 KPK.

${ }^{8}$ Zob. kan. $1425 \$ 4$ KPK. W myśl kan. $1590 \$ 2$ KPK, ustawodawca dopuszcza też zlecenie audytorowi sprawy wpadkowej, jeśli ta powinna być rozstrzygnięta przez trybunał w formie dekretu.

${ }^{9}$ Zob. kan. 1704 \& 1-2 KPK.

${ }^{10}$ Jeśli chodzi o uprawnienia sędziego instruktora w procesie o orzeczenie nieważności małżeństwa w trybie skróconym, G. Núñez uznaje je za wiele szersze niż te, które w myśl KPK posiadał instruktor lub audytor, i wprost traktuje o zupełnie nowej figurze prawnej, która skupia w sobie i funkcje sędziego instruktora, i te, które dotychczasowe ustawodawstwo przyznawało sędziemu audytorowi. Swój wywód na ten temat autor konkluduje następująco: „Teniendo en cuenta esta circunstancia, lo lógico sería considerar que este instructor tenga las más amplias facultades para desarrollar su labor, a lo que parece aludirse en lo dispuesto en el nuevo c. 1686: es decir, consideramos que debe ser una nueva figura que asuma las funciones
} 
kolegium $^{11}$, jedynie wypełnia ściśle określone, niekiedy jednostkowe i drobne zadania z zakresu postępowania dowodowego, o tyle sędzia instruktor wykonuje w procesie zadania o wiele bardziej znaczące. On w istocie sam prowadzi wspomniane postępowanie dowodowe, odpowiada za zebranie kompletu środków dowodowych, czuwa nad sprawnym i zgodnym z prawem tokiem instrukcji, jest do dyspozycji biskupa diecezjalnego jako konsultant, a tym samym może mieć pośrednio niemały wpływ na treść orzeczenia w sprawie. Jakkolwiek formalnie nie wypowiada się on, jak członek kolegium ${ }^{12} \mathrm{i}$ asesor, co do meritum sprawy, zaangażowanie sędziego instruktora w przeprowadzenie instrukcji procesu w pewnym sensie implikuje dalsze losy sprawy.

Należy zaznaczyć, że sędzia instruktor, do którego kompetencji należą wybrane czynności o charakterze procesowym od zawiązania sporu aż po zamknięcie postępowania dowodowego, może wykonywać swoje zadania wyłącznie w granicach otrzymanego zlecenia ${ }^{13}$. Zgodnie z kan. $133 \$ 1$ KPK działałby on nieważnie, gdyby przekroczył granice swojego zlecenia dotyczące rzeczy lub osób ${ }^{14}$. Innymi słowy, do wymienionego sędziego należy wyłącznie zebranie środków dowodowych i przekazanie ich biskupowi diecezjalnemu. W ramach realizacji tego zadania może on co najwyżej zdecydować, jeżeli wyraźnie nie zabroniono tego w zleceniu sędziego, które dowody i w jaki

desarrolladas por el juez instructor-auditor de la anterior legislación". G. NúÑEZ, El proceso brevior: exigencias y estructura, Ius Canonicum 56 (2016) s. 147.

${ }^{11}$ Audytor wyznaczony spośród członków kolegium sędziowskiego posiada wszelkie prawa, które wynikają z tego urzędu, w tym prawo do głosowania co do meritum sprawy.

${ }^{12} \mathrm{P}$. Moneta wyraźnie zaznacza, że instruktor w procesie skróconym $\mathrm{w}$ istocie nie jest sędzią. Autor stwierdza: „[...] il Vicario provvede a nominare non un giudice (come avviene nel processo ordinario), ma un istruttore, al quale verrà affidata tutta l'istruttoria della causa, sino alla soglia della decisione finale. P. Moneta, $L a$ dinamica processuale nel m.p. „Mitis Iudex”, Ius Ecclesiae 28(2016)2, s. 15 http:// www.consociatio.org/repository/Moneta_Lumsa.pdf [dostęp: 1-07-2019].

${ }^{13}$ Zob. kan. $1428 \S 3$ KPK. DC, art. $50 \S 3$.

${ }^{14}$ Por. kan. $1428 \S 3$ KPK. 
sposób powinny być zebrane, gdy co do tej sprawy wyłoni się kwestia podczas wykonywanego przezeń zadania ${ }^{15}$.

Biskup diecezjalny może ustanowić jednego lub kilku sędziów instruktorów, zlecając im przeprowadzenie instrukcji we wszystkich lub określonych sprawach. Sędzia jednoosobowy lub przewodniczący kolegium może wyznaczyć instruktora dla przeprowadzenia instrukcji wyłącznie w tej sprawie, którą sam rozpoznaje ${ }^{16}$. Wikariusz sądowy wreszcie ma obowiązek ustanowić instruktora w sprawie, która na mocy MIDI, powinna być rozstrzygnięta w ramach procesu skróconego ${ }^{17}$.

Munus sędziego instruktora można powierzyć wyłącznie wiernym chrześcijanom, duchownym lub świeckim, którzy wyróżniają się dobrymi obyczajami, mądrością i wiedzą ${ }^{18}$. Instruktorem może być także jeden $\mathrm{z}$ członków kolegium, a nawet jego przewodniczący ${ }^{19}$. Jeśli chodzi o proces skrócony, wikariusz sądowy może wyznaczyć jako instruktora także siebie ${ }^{20}$, o ile biskup diecezjalny nie postanowi

\footnotetext{
${ }^{15}$ Zob. kan. $1428 \$ 3$ KPK.

${ }^{16}$ Por. kan. 1428 \$ 1 KPK. Może on zlecić wspomniane zadanie któremuś z sędziów diecezjalnych lub jednej z osób zatwierdzonych przez biskupa diecezjalnego do sprawowania tej funkcji. Por. tamże.
}

${ }^{17}$ Por. kan. 1685 MIDI.

${ }^{18}$ Por. kan. $1428 \$ 2$ KPK; DC, art. $50 \$ 2$. Wprawdzie formalnie można ustanowić instruktorem w procesie skróconym także wiernego świeckiego, który posiada wymienione wyżej kwalifikacje osobowe, niemniej natura tego postępowania zdaje się wskazywać, iż bardziej zasadne byłoby powierzenie tego szczególnego urzędu kościelnego duchownemu.

${ }^{19}$ Do ustanowienia instruktora w osobie przewodniczącego kolegium wystarczy milcząca zgoda tegoż kolegium. Por. F. BĄczkowicz, Prawo kanoniczne. Podręcznik dla duchowieństwa, t. III, Opole 1958, s. 30.

${ }^{20}$ Jak zauważa Julián Ros Córcoles, objęcie przez wikariusza sądowego urzędu instruktora w procesie skróconym może służyć sprawnemu poprowadzeniu takiego postępowania i poznaniu obiektywnej prawdy. „A este respecto, en la praxis del tribunal eclesiástico se ha manifestado la conveniencia de que el vicario judicial se designe a sí mismo como instructor, posibilidad contemplada en el artículo 16 de las Reglas de procedimiento. En efecto, el principio de inmediación en el proceso se puede salvaguardar mejor así, teniendo en cuenta que la certeza que permitió al vicario judicial optar por la vía del proceso brevior le podrá ayudar a dirigir la 
inaczej. W przypadku jednak, kiedy wikariusz sądowy kieruje trybunałem międzydiecezjalnym, powinien ustanowić, o ile jest to możliwe, instruktora $\mathrm{z}$ diecezji, $\mathrm{z}$ której pochodzi rozpoznawana sprawa ${ }^{21}$. Zgodnie z dyspozycją kan. $1448 \$ 1-2$ KPK sędzia instruktor nie powinien przyjmować sprawy o orzeczenie nieważności małżeństwa w procesie skróconym, „w której w jakiś sposób jest zainteresowany $\mathrm{z}$ racji pokrewieństwa lub powinowactwa, w jakimkolwiek stopniu linii prostej i aż do czwartego stopnia linii bocznej, albo z racji sprawowania opieki i kurateli, wielkiej zażyłości czy niechęci, spodziewanej korzyści lub uniknięcia szkody”. Gdyby w przypadkach, o jakich jest mowa wyżej, instruktor nie powstrzymał się od urzędu, strona procesowa może domagać się jego wyłączenia ${ }^{22}$.

Osoba, której zlecono dokonanie instrukcji w określonej sprawie, nie może później ważnie w tej samej sprawie w innej instancji wyrokować jako sędzia lub pełnić w niej zadania asesora ${ }^{23}$. Duchownego lub świeckiego, który spełnia zadanie instruktora w jakiejś sprawie, należy też uznać za niezdolnego do składania zeznań w tej sprawie. Wreszcie osoba, która na mocy zlecenia biskupa diecezjalnego prowadziła dochodzenie wstępne, o jakim jest mowa w kan. $1717 \$ 1$ $\mathrm{KPK}^{24}$, nie może później, jeśli zostaje wszczęty proces karny sądowy, być w nim sędzią ${ }^{25}$.

instrucción de la causa de modo que ofrezca al obispo unos medios de prueba más sólidos y articulados con vistas al pronunciamiento de la sentencia”. J. Ros CórCOLEs, El vicario judicial y el instructor en los procesos de nulidad matrimonial tras el motu proprio Mitis Iudex, [art. cyt.], s. 100.

${ }^{21}$ Zob. art. 16 MIDI.

${ }^{22}$ Por. Kan. 1449 KPK. L. De RusCHI, El processus brevior del motu proprio Mitis Iudex Dominus Iesus. Una interpretación doctrinal, [art. cyt.], s. 220.

${ }^{23}$ Por. kan. 1447 KPK.

${ }^{24}$ We wspomnianym postępowaniu osoba taka posiada uprawnienia i obowiązki jak audytor w procesie. Zob. kan. $1717 \$ 3$ KPK.

${ }^{25}$ Por. kan. 1717 \& 3 KPK. 


\section{Szczególne obowiązki i prawa instruktora w sprawach rozpoznawanych $\mathrm{w}$ procesie skróconym}

Proces skrócony, ustanowiony wyłącznie w celu rozpatrywania spraw, w których istnieją najbardziej ewidentne przesłanki nieważności małżeństwa ${ }^{26}$, stanowi w istocie postępowanie, które - jak przyznaje sam Franciszek - „bardzo może zagrozić zasadzie nierozerwalności małżeństwa"27. Jest oczywiste, że zasadniczym źródłem tego niebezpieczeństwa jest ograniczona do minimum procedura, kiedy to, po zapoznaniu się z żądaniem obojga małżonków i zgromadzeniu "dowodów, które mogłyby być natychmiast zebrane przez sędziego"28, biskup diecezjalny bezzwłocznie wydaje orzeczenie w sprawie.

Ten skrócony do minimum tok postępowania ustawodawca w znacznej mierze powierza instruktorowi, którego wikariusz sądowy powinien powołać $\mathrm{w}$ tym samym dekrecie, w którym określa formułę wątpliwości ${ }^{29}$. Nie podlega dyskusji, iż jedynie skrupulatne i zgodne $\mathrm{z}$ zasadami prawa materialnego i formalnego wykonanie przez tego sędziego wszystkich i poszczególnych zadań o charakterze procesowym może stanowić gwarancję wydania wyroku z poszanowaniem prawa kanonicznego, w tym $\mathrm{z}$ respektem dla zasady nierozerwalności małżeństwa ${ }^{30}$. Zasadne jest zatem określenie tych szczególnych obowiązków i praw, które spoczywają na osobie sędziego instruktora powołanego do przeprowadzenia postępowania dowodowego w procesie skróconym.

\footnotetext{
${ }^{26}$ Por. MIDI, III.

${ }^{27}$ Tamże, IV.

${ }^{28}$ Kan. 1684 nr 2 MIDI.

${ }^{29}$ Zob. kan. 1685 MIDI.

${ }^{30} \mathrm{G}$. Pindi określa wspomnianą zasadę prawa jako „le principe non négociable de l'indissolubilité du lien matrimonial" i nadmienia, iż nie jest ona czymś nowym w reformie prawa małżeńskiego, dokonanej przez Franciszka, i w procesie o stwierdzenie nieważności małżeństwa. G. PINDI, La procédure de nullité matrimoniale devant l'évêque diocésain selon Mitis Iudex Dominus Iesus, dz. cyt., s. 11-12.
} 


\subsection{Bezzwłoczne dokonanie instrukcji sprawy}

Podstawowym zadaniem sędziego instruktora jest natychmiastowe zebranie dowodów w sprawie. O bezzwłocznym charakterze instrukcji sprawy w procesie skróconym świadczą między innymi dyspozycje zawarte w kan. 1684 nr 2, 1685 i 1686 MIDI, gdzie ustawodawca wprost zaznacza, że chodzi tu o „dowody, które mogłyby być natychmiast zebrane" ${ }^{\prime \prime}$, oraz - o ile to możliwe - dowody te należy zebrać podczas jednego posiedzenia ${ }^{32}$, które powinno się odbyć nie później niż trzydzieści dni od zawiązania sporu ${ }^{33}$.

Instrukcję sprawy w procesie skróconym instruktor powinien rozpocząć z chwilą powołania go na wymieniony urząd, czyli zaraz po określeniu przez wikariusza sądowego formuły wątpliwości. Naturalnie sędzia instruktor może de facto przeprowadzić postępowanie dowodowe tylko wtedy, gdy przynajmniej jedna ze stron stawiła się na posiedzenie sądu, podczas którego, o ile to możliwe, należy zebrać wszystkie środki dowodowe. Gdyby nie zgłosiła się na wspomnianą sesję strona pozwana, może być uznana za oporną prawu i sprawa winna być prowadzona bez jej udziału ${ }^{34}$. Gdyby nie stawiła się strona powodowa, sprawa powinna zostać zawieszona, chyba że chciałaby ją przejąć strona pozwana.

Jakkolwiek ustawodawca postanawia, że „orzekanie w sprawach o nieważność małżeństwa w procesie skróconym” jest możliwe tylko wówczas, gdy „przytaczane są okoliczności dotyczące faktów lub osób, poparte zeznaniami lub dokumentami, które nie wymagają przeprowadzenia dokładniejszego badania albo dochodzenia oraz w sposób oczywisty wskazują na nieważność" 35 , nie oznacza to bynajmniej, że postępowanie dowodowe, za którego wdrożenie i przeprowadzenie

\footnotetext{
${ }^{31}$ Kan. 1684 nr 2 MIDI.

${ }^{32}$ Zob. kan. 1686 MIDI.

${ }^{33}$ Por. kan. 1685 MIDI.

${ }^{34}$ Naturalnie, jest tu mowa o sytuacji, kiedy strona pozwana, nieobecna podczas wymienionego posiedzenia sądu, wcześniej spełniła wymóg określony w kan. 1683 nr 1 MIDI, czyli zgłosiła żądanie razem ze współmałżonkiem lub przynajmniej zgodziła się na zgłoszenie tego żądania w sądzie.

${ }^{35}$ Kan. 1683 nr 2 MIDI.
} 
odpowiada sędzia instruktor, ma być dokonane pobieżnie i bez należnej staranności ${ }^{36}$. Wprost przeciwnie, świadomość tego, że chodzi o stwierdzenie nieważności małżeństwa w trybie skróconym winna wręcz dopingować tego sędziego i wszystkich innych uczestników procesu do tego, aby ustrzec się nawet pozorów nierzetelności w zakresie przestrzegania wymogów proceduralnych, podejrzenia o pobieżną ocenę dowodów i faktów czy pochopnej łatwowierności, która nie ma nic wspólnego z posługą na rzecz prawdy.

Ze względu na charakter tytułu nieważności małżeństwa, jaki $\mathrm{w}$ żądaniu mogą wskazać strony procesowe, niektóre $\mathrm{z}$ dowodów powinny być w zasadzie dołączone już do skargi powodowej ${ }^{37}$. Gdyby strona powodowa nie przedstawiła takich dowodów, instruktor winien poinformować ją o takim obowiązku. Pośród środków dowodowych, które mogą potwierdzić słuszność „najbardziej ewidentnych przesłanek nieważności małżeństwa"38 i które można by przedstawić wraz ze skargą powodową, należy wymienić następujące dokumenty publiczne i prywatne: „dokument medyczny, który

${ }^{36}$ Por. DC, art. $33 \$ 2$. W instrukcji tej zaznaczono wyraźnie, że „uwzględniając powagę i trudność spraw o nieważność małżeństwa, biskupi powinni zadbać, aby [pracownicy wymiaru sprawiedliwości] wybrani do wykonywania tej funkcji swoje obowiązki wykonywali starannie i zgodnie z zasadami prawa”. „W procesach o orzeczenie nieważności małżeństwa chodzi o ustalenie prawdy obiektywnej dotyczącej ważności lub nieważności węzła małżeńskiego. Dlatego procesy te powinny być przeprowadzone bardzo starannie, tak aby sędzia mógł wydać sprawiedliwą decyzję, opartą tylko i wyłącznie na prawdzie, która [...] w każdym procesie kościelnym, od początku do końca, jest fundamentem, matką i prawem sprawiedliwości”. P. MALECHA, Gwarancja sprawiedliwości oraz reforma procesu małżeńskiego widziana przez pryzmat konieczności jego przyśpieszenia i ułatwienia wiernym kontaktu z trybunałem; przygotowanie pracowników i odpowiedzialność biskupa, Roczniki Nauk Prawnych 25 (2015) nr 4, s. 170.

${ }^{37}$ Ustawodawca wprost domaga się, aby „skarga powodowa, która rozpoczyna proces skrócony, oprócz tego, co jest wymienione w kan. 1504, winna [...] zawierać w załączeniu dokumenty, na których opiera się żądanie” (kan. 1684 nr 3 MIDI).

${ }^{38}$ MIDI, III. 
w sposób oczywisty wyklucza konieczność zasięgnięcia opinii biegłego z urzędu" ${ }^{39}$; dokument potwierdzający akt apostazji, wskazujący na „taki brak wiary, który może prowadzić do symulacji konsensu [małżeńskiego] lub błędu determinującego wolę" ${ }^{40}$; orzeczenie sądu o rozwodzie cywilnym stron, potwierdzające „krótki czas pożycia małżeńskiego" "41; pamiętnik, list lub dokument medyczny potwierdzający przeprowadzenie aborcji „dokonanej dla uniknięcia zrodzenia potomstwa" ${ }^{42}$; diariusz, pamiętnik, zdjęcie, list lub inny nośnik informacji, w którym zawarto dane potwierdzające „pozostawanie w relacji pozamałżeńskiej w czasie zawierania małżeństwa lub wkrótce po zaślubinach” ${ }^{43}$ albo „zawarcie małżeństwa z przyczyny całkowicie obcej życiu małżeńskiemu"44; epikryza o niepłodności lub bezpłodności strony, sporządzona przed zawarciem małżeństwa, potwierdzająca „podstępne zatajenie bezpłodności” ${ }^{45}$; dokumenty wskazujące na „użycie przemocy fizycznej w celu wymuszenia konsensu” 46 ; dokumentacja medyczna lub prawna, w której „potwierdzono brak używania rozumu" ${ }^{47}$; oświadczenie złożone wobec notariusza lub pisemna deklaracja sporządzona na okoliczność zawarcia małżeństwa, potwierdzające wykluczenie istotnego przymiotu lub istotnego elementu małżeństwa ${ }^{48}$; akt urodzenia potomstwa z wcześniejszego

\footnotetext{
${ }^{39}$ Art. $14 \$ 2$ MIDI. Takim środkiem dowodowym może być m.in.: epikryza z kliniki psychiatrycznej; inna dokumentacja leczenia psychiatrycznego; opinia biegłego psychologa sporządzona w innym postępowaniu sądowym (np. ekspertyza wykonana na wniosek Sądu Rodzinnego w sprawie o ustalenie miejsca pobytu małoletnich dzieci stron; opinia biegłego psychiatry w procesie karnym, wszczętym przeciwko jednej ze stron).

${ }^{40}$ Art. $14 \$ 1$ MIDI.

${ }^{41}$ Tamże.

42 Tamże.

${ }^{43}$ Tamże.

${ }^{44}$ Tamże.

${ }^{45}$ Tamże.

${ }^{46}$ Tamże.

${ }^{47}$ Por. art. $14 \$ 1$ MIDI.

${ }^{48}$ Por. Dec. c. Sabattani z 25 V 1963 r., SRRDec. 55 (1972) s. 282-283; Dec. c. De Jorio z 29 IV 1964 r., SRRDec. 56 (1973) s. 316-317; Dec. c. Ewers z 25 VI 1966 r.,
} 
związku lub dokument sprzed małżeństwa stwierdzający poważną chorobę zakaźną albo przebywanie w zakładzie penitencjarnym, stanowiące potwierdzenie podstępnego zatajenia przymiotu osoby.

Jeśli chodzi o przyjęcie wyżej wymienionych dokumentów, jest zrozumiałe, że instruktor może dopuścić tylko te spośród nich, które są autentyczne, godziwe i pożyteczne do poznania sprawy ${ }^{49}$. W przypadku pozytywnej wątpliwości co do autentyczności danego dokumentu powinien on skorzystać z ekspertyzy biegłego sądowego. Ostateczna decyzja co do godziwości danego dowodu i jego znaczenia prawnego należy do biskupa diecezjalnego ${ }^{50}$.

\subsection{Zebranie dowodów w sprawie, o ile to możliwe podczas jednego posiedzenia sądu}

Wszystkie dowody, za wyjątkiem tych dołączonych do skargi powodowej, instruktor, o ile jest to możliwe, powinien zebrać podczas jednego posiedzenia sądu. Datę i miejsce tej sesji winien określić wikariusz sądowy w tym samym dekrecie, w którym ustalono formułę wątpliwości. Jeśli we wspomnianym dekrecie nie znalazło się stosowne pouczenie stron o naturze tego posiedzenia sądu, konieczności przedłożenia dowodów w sprawie i sposobie przeprowadzania dowodów, sędzia instruktor może, w imię troski o pełne rozpoznanie sprawy, poinformować strony o szczególnym charakterze postępowania dowodowego w procesie skróconym. Jest to zasadne zwłaszcza wtedy, gdy strony procesowe nie powołały pełnomocnika i/lub adwokata $^{51}$, oraz istnieje obawa, że z powodu ignorancji, błędu lub

SRRDec. 58 (1975) s. 442; Dec. c. Raad z 5 II 1981 r., RRDec. 73 (1987) s. 74; Dec. c. Fiore z 25 VI 1983 r., RRDec. 75 (1988) s. 374; Dec. c. Bruno z 22 VI 1984 r., RRDec. 76 (1989) s. 382-383; Dec. c. Giannecchini z 20 XII 1986 r., RRDec. 78 (1991) s. 778 -779; Dec. c. Boccafola z 5 III 1987 r., RRDec. 79 (1992) s. 86-87; Dec. c. Ragni z 23 VI 1987 r., RRDec. 79 (1992) s. 383-385; Dec. c. Stankiewicz z 19 V 1988 r., RRDec. 80 (1993) s. 329; Dec. c. Bottone z 21 XI 2002 r., RRDec. 94 (2010) s. 665.

${ }^{49}$ Por. kan. $1527 \$ 1$ KPK.

${ }^{50}$ Por. kan. 1683 MIDI.

${ }^{51}$ Należy tu pamiętać, że strony, które domagają się orzeczenia nieważności małżeństwa, „mogą powołać pełnomocnika różnego od adwokata” (DC, art. $103 \$ 1$ ), 
opieszałości mogą nie skorzystać w pełni z prawa do obrony. Jeśli wreszcie w wymienionym wyżej dekrecie wikariusza sądowego nie zawarto informacji o tym, że strony „nie później niż na trzy dni przed posiedzeniem dowodowym, mogą złożyć propozycje kwestii niezałączonych do skargi powodowej, co do których proszą o przesłuchanie stron lub świadków" 52 , sędzia instruktor winien w swoim dekrecie uzupełnić ten brak.

Nader ważnym i odpowiedzialnym zadaniem instruktora w procesie skróconym jest przewodniczenie posiedzeniu, o którym jest mowa w kan. 1685 i 1686 MIDI. Jakkolwiek prawo nie zabrania, aby w takiej sesji sądu brał też udział biskup diecezjalny, który mógłby nawet zastrzec sobie przewodniczenie posiedzeniu ${ }^{53}$, zasadne jest,

a nawet równocześnie kilku adwokatów (zob. kan. $1482 \$ 3$ KPK, DC, art. $103 \$ 4$ ). Jeśli zaś prośbę o orzeczenie nieważności małżeństwa przedstawili oboje małżonkowie (si ambo coniuges nullitatis matrimonii declarationem petant), „mogą powołać sobie wspólnego pełnomocnika lub adwokata” (DC, art. 102).

${ }^{52}$ Art. 17 MIDI.

${ }^{53}$ Bezpośredni udział Biskupa diecezjalnego w takim posiedzeniu niekoniecznie jest wskazany z racji czysto pastoralnych. Biskup diecezjalny tym bardziej powinien powstrzymać się od przewodniczenia sesji sądu. Należy bowiem pamiętać, że jakkolwiek obie strony zgodnie proszą o poprowadzenie postępowania skróconego i podzielają stanowisko co do tytułu nieważności małżeństwa, nie można wykluczyć kłótni małżonków podczas posiedzenia, konfliktu ich interesów, różnicy stanowisk stron i świadków w kwestiach szczególnych itp. W imię zachowania najwyższego obiektywizmu w rozstrzyganiu co do meritum sprawy biskup diecezjalny winien raczej unikać takich sytuacji, w których przyjdzie mu przyznać rację jednej lub drugiej stronie procesowej. Konieczną zaś wiedzę na temat stron i ich zachowania podczas wymienionego posiedzenia może on pozyskać z akt sprawy oraz relacji sędziego instruktora, tym bardziej, że ustawodawca postanawia, by, „po otrzymaniu akt”, biskup diecezjalny, zanim wyda wyrok w sprawie, skonsultował się m.in. $z$ instruktorem. Zob. kan. $1687 \$ 1$ MIDI. Nie należy też tu zapominać o jasnej dyspozycji zawartej w art. 22 DC. Bezpośrednio po potwierdzeniu treści kan. 1419 $\$ 1 \mathrm{KPK}$ i przypomnieniu, że „w każdej diecezji sędzią pierwszej instancji dla spraw o nieważność małżeństwa wprost przez prawo niewyjętych jest biskup diecezjalny, który może [...] wykonywać władzę sądową osobiście lub przez innych” (\$1), zaznaczono tam wyraźnie: „Zaleca się jednak, aby bez specjalnych powodów [biskup diecezjalny - J.K.] nie wykonywał tej władzy osobiście” (\$2). 
zwłaszcza w przypadku, kiedy biskup diecezjalny nie jest kanonistą, aby samo zbieranie dowodów podczas takiego posiedzenia było realizowane pod kierownictwem sędziego instruktora.

Instruktor winien tak moderować wspomniane posiedzenie sądu, aby faktycznie, o ile to jest możliwe, zostały zgromadzone wszystkie dowody podczas tej jednej sesji. W tym celu powinien on, zgodnie $\mathrm{z}$ tym, co postanowiono w kan. $1686 \mathrm{KPK}$, pominąć $\mathrm{w}$ ramach tego posiedzenia formalności zwyczajnego procesu ${ }^{54} \mathrm{i}$ wdrożyć wyłącznie te zasady, które nakazał w tym przypadku stosować ustawodawca. Innymi słowy, na wzór procedury przewidzianej w procesie opartym na dokumentach, instruktor powinien poprzestać na sprawnym przyjęciu oświadczeń stron i zeznań świadków, indagowanych jedynie o to, co budzi wątpliwości po zapoznaniu się z treścią skargi i zgłoszonymi dowodami ${ }^{55}$. Jeśli zaś mowa o oświadczeniach składanych przed sądem, zeznaniach świadków i wnioskach innych uczestników posiedzenia, powinien on polecić notariuszowi spisanie wyłącznie tego, co dotyczy meritum i jest pożyteczne do poznania sprawy. Sam protokół z posiedzenia sądu winien zawierać tylko istotne kwestie, i to opisane w sposób sumaryczny ${ }^{56}$. Jest zrozumiałe, że instruktor powinien też dopilnować, aby protokół ten został zredagowany w trakcie trwania poszczególnych czynności procesowych, tak by osoby składające

\footnotetext{
${ }^{54}$ Zob. kan. 1685 MIDI.

${ }^{55}$ Naturalnie, sędzia instruktor winien przypomnieć stronom i świadkom o poważnym obowiązku mówienia całej prawdy i tylko prawdy oraz nakazać im złożenie stosownej przysięgi lub przynajmniej obietnicy zeznania prawdy. Por. kan. 1532, $1562 \S 1-2$ KPK; DC, art. $167 \S 1-2$.

${ }^{56}$ „Odpowiedzi stron i świadków powinny być zredagowane na piśmie przez notariusza, lecz sumarycznie i w tym tylko, co należy do istoty małżeństwa będącego przedmiotem sporu". MIDI, art. $18 \$ 2$. Należy tu zastrzec, że wspomniane odpowiedzi winny być spisane przez notariusza w sposób dosłowny, czyli w formie, w jakiej złożono zeznanie. Por. kan. $1567 \$ 1$ KPK; DC, art. $173 \$ 1$. „En tanto que dominus de la sesión de recogida de pruebas recae sobre el instructor la responsabilidad de que se recojan las respuestas de las partes y de los testigos de modo sumario y exclusivamente en lo que se refiere a la sustancia del matrimonio cuya nulidad debe declarar el obispo". J. Ros CóRCOLEs, El vicario judicial y el instructor en los procesos de nulidad matrimonial tras el motu proprio Mitis Iudex, [art. cyt.], s. 100.
} 
oświadczenia, zeznające w sprawie lub prezentujące wnioski mogły natychmiast go podpisać. Jeśli wreszcie, zdaniem sędziego instruktora, we wspomnianej zwięzłej relacji z posiedzenia sądu należałoby nadmienić o pewnych szczególnych zachowaniach uczestników sesji, mogących mieć wpływ na treść orzeczenia w sprawie, powinien on polecić notariuszowi sporządzenie stosownych uwag.

Jeśli mowa o poszczególnych uczestnikach posiedzenia dowodowego sądu, wszystkie te osoby powinny być wezwane na wspomnianą sesję przez wikariusza sądowego, i to w tym samym dekrecie, w którym określono formułę wątpliwości ${ }^{57}$. Gdyby jednak, po dokonaniu wymienionego wezwania przez wikariusza sądowego, wynikła potrzeba wezwania jeszcze innych osób, na przykład celem wyjaśnienia wątpliwości, które pojawiły się po zapoznaniu się z treścią skargi powodowej i nieznanymi wcześniej dowodami, instruktor powinien - o ile nie zabroniono tego wprost w zleceniu - wezwać stosownym dekretem te osoby ${ }^{58}$.

Sędzia instruktor powinien dopuścić na aulę, do udziału we wspomnianym posiedzeniu dowodowym sądu, tylko te osoby, które należy uznać za konieczne do prowadzenia procesu ${ }^{59}$. W praktyce będą to: notariusz; obrońca węzła małżeńskiego ${ }^{60}$; obie strony procesowe wraz $\mathrm{z}$ adwokatami, jeśli korzystają $\mathrm{z}$ ich pomocy prawnej ${ }^{61}$; świadkowie

\footnotetext{
${ }^{57}$ Por. kan. 1685 MIDI.

${ }^{58}$ Por. kan. $1428 \$ 3$ KPK. Gdyby taki formalny zakaz, dotyczący tego, które dowody i w jaki sposób powinny być zebrane przez instruktora, znalazł się w zleceniu wikariusza sądowego, sędzia instruktor przekonany o potrzebie wezwania nowych uczestników posiedzenia sądu, o jakim jest mowa w kan. 1685 MIDI, powinien poprosić o dokonanie takiego wezwania oficjała sądu. Naturalnie, decyzja co do zasadności wystosowania takiego wezwania należy do wikariusza sądowego. Gdyby jednak oficjał nie dokonał tego wezwania, a zdaniem instruktora udział tych osób mógłby mieć wpływ na stopień poznania sprawy, powinien nadmienić o tym fakcie biskupowi diecezjalnemu w finalnej relacji z przeprowadzenia instrukcji sprawy.

${ }^{59}$ Por. kan. $1470 \$ 1$ KPK; DC, art. 86.

${ }^{60}$ Ten nie musi de facto uczestniczyć w posiedzeniu sądu, powinien być jednak poinformowany o miejscu i czasie jego zwołania.

${ }^{61}$ Sędzia instruktor nie może dopuścić na aulę pełnomocników stron. O ile bowiem w zwykłym procesie spornym w czasie przesłuchania stron, świadków i biegłych
} 
zgłoszeni w sprawie, o ile ich nie wykluczono ${ }^{62}$; biegli, jeśli tak przewiduje ustawa lub zostało to uznane za potrzebne ${ }^{63}$; rzecznik sprawiedliwości, jeśli występuje w procesie ${ }^{64}$. Wszyscy uczestnicy posiedzenia sądu mogą brać w nim udział w sposób czynny. Naturalnie, składanie przez nich oświadczeń, zeznań i wniosków winno odbywać się $\mathrm{z}$ zachowaniem należnego porządku. Za zachowanie tego porządku odpowiada moderator posiedzenia sądu, czyli sędzia instruktor.

Jeśli mowa o kolejności składania oświadczeń i zeznań oraz o udziale osób trzecich w przesłuchaniach stron i świadków, decyzja w tym przypadku należy do sędziego instruktora. Jeśli więc uzna on, że strony i ich adwokaci, którzy mają prawo uczestniczyć w przesłuchaniu drugiej strony i świadków, ze względu na określone okoliczności rzeczowe i osobowe, nie powinni brać udziału w takim przesłuchaniu, winien odmówić im prawa wejścia na aulę sądu ${ }^{65}$.

mogą być obecni adwokaci i pełnomocnicy stron (por. kan. 1559 KPK), o tyle w sprawach o orzeczenie nieważności małżeństwa - co wyraźnie podkreślono w art. 159 $\$ 1 \mathrm{nr} 1 \mathrm{DC}$ - prawo udziału w przesłuchaniach przysługuje jedynie adwokatom. Jak zauważa G. Erlebach, „Stanowisko zajęte przez DC stanowi rozstrzygnięcie niejasności związanej z terminem patronus (obrońca) w KPK 83 (zob. kan. 1678 \$1; 1490). W praktyce Roty Rzymskiej patronus oznacza adwokata, który pełni zarazem funkcję pełnomocnika”. G. ErLebAch, Niektóre procesy specjalne, w: G. Erlebach, A. Dzięga, J. Krukowski, R. Sztychmiler, Komentarz do Kodeksu Prawa Kanonicznego. T. V. Ks. VII Procesy, Pallottinum, Poznań 2007, s. 346.

${ }^{62}$ Kwestię wykluczenia świadka rozstrzyga quam primum sam sędzia instruktor, chyba że wprost w zleceniu wikariusza sądowego zostało to zakazane. W tym ostatnim przypadku wspomnianą kompetencję posiada ten, kto w myśl kan. 1685 MIDI wzywa wszystkich, którzy powinni wziąć udział w posiedzeniu sądu, czyli wikariusz sądowy. Por. kan. $1428 \$ 3 \mathrm{KPK}$.

${ }^{63}$ Por. kan. 1574, 1680 KPK; DC, art. $203 \$ 1$ 1-2; G. PINDI, La procédure de nullité matrimoniale devant l'évêque diocésain selon Mitis Iudex Dominus Iesus, dz. cyt., s. 165 .

${ }^{64}$ Por. kan. $1677 \$ 1$ MIDI.

${ }^{65}$ Por. art. $18 \$ 1$ MIDI; PH. Toxé, La réforme des procès en nullité de mariage selon le motu proprio Mitis Iudex Dominus Iesus, [art. cyt.], s. 122. „El motivo de la negativa a la presencia de las partes proviene de la peculiaridad de la prueba testifical: las declaraciones suelen tener un carácter íntimamente personal y, por otra parte, parece necesario tutelar la libertad de los testigos y de los peritos. De ahí que de 
Jeśli zaś chodzi o składanie zeznań przez świadków występujących w sprawie o orzeczenie nieważności małżeństwa w procesie skróconym, zgodnie $\mathrm{z}$ kan. $1560 \$ 1 \mathrm{KPK}$, „powinni być przesłuchiwani osobno i pojedynczo" ${ }^{16}$.

Jakkolwiek żądanie w prowadzonym procesie skróconym „zostało zgłoszone przez obydwoje małżonków lub przez jednego z nich za zgodą drugiego" ${ }^{67}$, instruktor powinien czuwać, aby podczas zbierania dowodów w trakcie posiedzenia, w którym bezpośrednio uczestniczą obie strony, zachowano należną powagę sądu i nie naruszono godności postępowania kanonicznego poprzez wszczęcie awantury między małżonkami, ostrą wymianę zdań między stronami a świadkami lub rękoczyny. Innymi słowy, zgodnie z art. $165 \$ 2$ DC, powinien on tak przesłuchiwać strony, świadków i biegłych, aby „uniknąć przy tym, o ile jest to możliwe, sporów i zgorszenia" ${ }^{6}$. Wskazane jest zarazem, aby sędzia instruktor skorzystał w tym przypadku

forma general se dispone que el juez o instructor, por lo delicado de alguna prueba, puede estimar que deba procederse en forma secreta al desarrollo de la misma [...]. Pensamos que el instructor deberá mostrar una sensibilidad especial para que en la vista no se produzcan situaciones que lesionen la fama o falten gravemente a la caridad de las partes". G. NúÑEZ, El proceso brevior: exigencias y estructura, [art. cyt.], s. 149.

Jak słusznie zauważa Felipe Heredia Esteban, sędzia audytor Roty Rzymskiej, instruktor winien mieć $\mathrm{w}$ tym przypadku na względzie ewentualny negatywny wpływ obecności stron procesowych na obiektywizm i szczerość zeznań świadków: „En cuanto a la ejecución de las pruebas, el artículo 18 [MIDI - J.K.] permite que las partes y sus abogados puedan estar presentes en los interrogatorios tanto de las otras partes como de todos los testigos, a no ser que el instructor por motivos fundados no lo considere oportuno; no podemos olvidar que el requisito de que ambos cónyuges pidan la nulidad permite presumir que la asistencia de ambos cónyuges durante su respectivo interrogatorio no dificulta la objetividad y sinceridad de cada uno de ellos, pero su presencia durante el interrogatorio de los testigos bien pudiera en cierto modo intimidar o al menos influir en sus testimonios". F.H. Esteban, El proceso más breve ante el obispo, „Anuario de Derecho Canónico” 5 Supl. [Octobre 2016], s. 115.

${ }^{66}$ Por. L. De RuschI, El processus brevior del motu proprio Mitis Iudex Dominus Iesus. Una interpretación doctrinal, [art. cyt.], s. 221.

${ }^{67} \mathrm{Kan} .1683$ nr 1 MIDI.

${ }^{68}$ Por. kan. $1560 \S 2$ KPK. 
z tego, co przewidziano $\mathrm{w}$ art. $65 \$ 2 \mathrm{DC}$, gdzie postanowiono: „[...] sędzia powinien zachęcić małżonków, aby pozostawiwszy wszelkie osobiste pragnienia, szczerze współpracowali, działając w prawdzie i z miłością, w poszukiwaniu prawdy obiektywnej, tak jak tego wymaga natura spraw małżeńskich”. Gdyby instruktor zauważył, że małżonkowie są do siebie wrogo nastawieni, powinien ich zachęcić, „aby w trakcie procesu, porzuciwszy wszelką niechęć, kierowali się nawzajem uprzejmością, dobrocią i miłością bliźniego"69. Wreszcie, w razie konieczności, sędzia instruktor może przywołać do porządku wszystkich uczestników rozprawy, którzy poważnie uchybili szacunkowi i posłuszeństwu należnym sądowi, zaś adwokatów i pełnomocników - o ile nie zastrzeżono tego w zleceniu - może także zawiesić $\mathrm{w}$ wykonywaniu zadania w sprawie $\mathrm{e}^{70}$.

Jest zrozumiałe, że przed przystąpieniem do przyjmowania oświadczeń stron i zeznań świadków wezwanych na posiedzenie sądu instruktor powinien zadbać, aby osoby te złożyły stosowną przysięgę oraz zatroszczyć się o zebranie świadectw wiarygodności ${ }^{71}$.

\subsection{Uzupełnienie instrukcji, jeśli podczas posiedzenia sądu, o jakim} jest mowa w kan. 1685 i 1686 MIDI, nie zebrano wszystkich dowodów

Czynności procesowe, o jakich jest mowa w kan. 1686 MIDI, których celem jest zebranie brakujących środków dowodowych, mają charakter warunkowy. Sędzia instruktor powinien je przedsięwziąć jedynie wówczas, gdy podczas posiedzenia sądu, o jakim jest mowa

\footnotetext{
${ }^{69} \mathrm{DC}$, art. $65 \$ 3$.

${ }^{70}$ Por. kan. $1470 \$ 2$; DC, art. 88.

${ }^{71}$ Por. kan. 1532 KPK. „Partes y testigos deberán prestar juramento de decir la verdad, tal como lo prescribe el canon 1532, y no se omitirá solicitar los testimonios de credibilidad de unos y otros, a los efectos de evaluar al fuerza probatoria de sus dichos, especialmente con relación a la confesión judicial y declaraciones de las partes sostenidas por eventuales testigos y a la deposición de un solo testigo, en el sentido de los parágrafos 1 y 2 del nuevo canon 1678”. L. DE Ruschi, El processus brevior del motu proprio Mitis Iudex Dominus Iesus. Una interpretación doctrinal, [art. cyt.], s. 221.
} 
w kan. 1685 i 1686 MIDI, nie udało się zebrać wszystkich dowodów w sprawie.

Pośród przyczyn, które de facto mogą uniemożliwić zebranie dowodów w sprawie o orzeczenie nieważności małżeństwa podczas jednego posiedzenia sądu, należy wymienić następujące: fizyczna niedostępność danego dowodu w chwili posiedzenia dowodowego sądu a w konsekwencji niemożliwość zdeponowania go w siedzibie trybunału i poddania stosownej ocenie; uprzednia, obiektywna trudność w pozyskaniu dowodu, o którego istnieniu wie przynajmniej jedna ze stron procesowych; niewykonanie na czas ekspertyzy co do autentyczności wcześniej przedłożonego dokumentu; obiektywna przeszkoda po stronie strony procesowej, świadka lub biegłego, uniemożliwiająca stawienie się na posiedzenie sądu w dniu określonym przez wikariusza sądowego ${ }^{72}$.

Jeśli mowa o posiedzeniu sądu, podczas którego - o ile to możliwe - instruktor powinien zebrać dowody, nie musi odbyć się ono jednego dnia ${ }^{73}$. W sytuacji, kiedy podczas wspomnianego posiedzenia nie udało się zebrać wszystkich dowodów w sprawie, sędzia instruktor

\footnotetext{
${ }^{72}$ Taką przeszkodę mogą stanowić m.in. następujące okoliczności: hospitalizacja, stan zdrowia, udział w ceremonii pogrzebowej, przebywanie w niewoli, areszcie lub więzieniu, znaczne oddalenie geograficzne. Por. R. Willot, Premiers procès plus brefs dans les diocèses de l'officialité de Lille, Revue de Droit Canonique 67 (2017) 1, s. 223.

${ }^{73}$ „Este canon [1686 MIDI - J.K.] manda a que el Instructor, en una sola sesión si fuere posible, recoja las pruebas ofrecidas. Es evidente que ante una posible incomparecencia de una de las partes o de algunos de los testigos propuestos, el Instructor deberá emplazarlos a comparecer cuanto antes”. L. DE RusCHI, El processus brevior del motu proprio Mitis Iudex Dominus Iesus. Una interpretación doctrinal, [art. cyt.], s. 221.

„Il s'agit là d'un problème pratique et il nous semble peu réaliste qu'endéans 30 jours on puisse préparer une telle session (y compris recevoir une éventuelle commission ragatoire) et réunir tous ceux qui doivent comparaître en une seule et même date. Le Législateur semble en être conscient car il a assorti son vœu de la restriction «quatenus fieri possit» (si possible)". P. HUBERT, «Ad certitudinem moralem iure necessariam..». La question des preuves à la lumière de motu proprio Mitis Iudex Dominus Iesus, Revue de Droit Canonique 67 (2017) 1, s. 114.
} 
może zarządzić przerwę w posiedzeniu, nawet na kilka dni, lub - jeśli uzna to za konieczne - zwołać kolejną sesję sądu, podczas której będzie można uzupełnić instrukcję sprawy ${ }^{74}$. W jednym i drugim przypadku posiedzenie sądu powinno odbyć się jak najszybciej, tzn., o ile to możliwe, przed upływem trzydziestu dni od określenia formuły wątpliwości, tak by zwłoka w realizacji postępowania dowodowego nie spowodowała opóźnienia w wydaniu orzeczenia w sprawie. Co więcej, ponieważ stosowana w tym przypadku zasada maksymalnej koncentracji ${ }^{75} \mathrm{~W}$ zakresie zbierania dowodów nie posiada $\mathrm{w}$ procesie skróconym charakteru absolutnego, sędzia instruktor może też dopuścić uzupełnienie instrukcji poza posiedzeniem sądu. Innymi słowy, ponieważ w procesie skróconym dyskusja i wydanie decyzji $\mathrm{w}$ sprawie następują potem, $\mathrm{tj}$. nie podczas tego samego posiedzenia sądu, wszyscy, którzy mają prawo do przedłożenia dowodów w sprawie, mogą to uczynić także po zakończeniu posiedzenia sądu, o jakim jest mowa w kan. 1685 i 1686 MIDI $^{76}$. Naturalnie, sędzia instruktor powinien zadbać w tym przypadku o zachowanie przewidzianych przez prawo terminów, tak by prolongowanie czasu składania dowodów nie okazało się w istocie formą obstrukcji procesowej, która uniemożliwi wydanie jak najszybciej wyroku w sprawie.

O konieczności zawieszenia posiedzenia sądu, podczas którego należy zebrać dowody, lub potrzebie jego ponownego zwołania w istocie mogą przesądzić wyłącznie poważne braki w zakresie zgromadzonego materiału dowodowego. Oczywiście, chodzi tu jedynie o dowody, które dają gwarancję wydania sprawiedliwego wyroku i są możliwe do przedstawienia w czasie przewidzianym na instrukcję sprawy. Sędzia instruktor, który wciąż winien pamiętać, że ustawodawca dopuszcza wdrożenie procesu skróconego tylko wtedy, gdy „skarga o nieważność

\footnotetext{
${ }^{74}$ Zob. kan. 1666 KPK.

${ }^{75}$ Zob. E. Frank, Juger ou faire juger: l'évêque diocésain juge dans le procès plus bref et le nouveau rôle du vicaire judiciaire à la lumière du motu proprio Mitis Iudex Dominus Iesus, Revue de Droit Canonique 67 (2017) 1, s. 133.

${ }^{76}$ Wspomniane dodatkowe dowody sędzia instruktor może przyjąć, jeśli są konieczne do poznania prawdy, a wcześniej nie mogły być zgłoszone.
} 
małżeństwa jest poparta szczególnie oczywistymi argumentami"77, nie może dopuścić działania na zwłokę i pozwolić na przedłużanie postępowania dowodowego w sprawie w nieskończoność. Wprost przeciwnie, świadom tego, że strony mogą też dochodzić prawdy co do własnej sytuacji kanoniczno-prawnej w drodze procesu zwyczajnego, kiedy biskup diecezjalny nie osiągnął pewności moralnej co do nieważności małżeństwa ${ }^{78}$, oraz że przysługuje im apelacja od wyroku biskupa ${ }^{79}$, powinien czuwać, by nie wypaczyć fundamentalnych zasad procesu skróconego. Inaczej, powinien on zadbać, aby faktyczne trwanie postępowania dowodowego nie sprawiło, że proces, który z natury swej jest skrócony, przekształci się de facto w proces zwyczajny.

\subsection{Ogłoszenie akt i dyskusja sprawy}

Z chwilą zebrania dostępnych dowodów w sprawie sędzia instruktor powinien bez żadnej zwłoki dokonać ogłoszenia akt. Wprawdzie, jak zauważa María Victoria Hernández Rodriguez, według MIDI nie ma w procesie skróconym miejsca na publikację akt, ponieważ ustawodawca nie przewidział jej wprost, niemniej należy pamiętać, że w prawie kanonicznym nie istnieje instytucja publikacji wewnętrznej (una publicidad interna), znanej na forum cywilnym. Wprost przeciwnie, w prawie kanonicznym obowiązuje zasada jawności (el principio de la publicidad), która oznacza, że nie istnieje żadna sekretna sprawiedliwość ani jakieś niejawne procedury ${ }^{80}$.

\footnotetext{
${ }^{77}$ MIDI, IV.

${ }^{78}$ Por. kan. 1687 \$ 1 MIDI.

${ }^{79}$ Por. kan. $1687 \$ 3$ MIDI.

${ }^{80}$ „En el processus brevior no queda - expresamente dispuesto por la norma - lugar para la publicación de las actas, y ello no puede quedar justificado con la presencia de partes, testigos, defensor del vínculo, abogados en la misma y única sesión de que debería constar la instructoria. Si una de las partes no se presenta a declarar en el día indicado por el instructor para la recogida de las pruebas, si el defensor del vínculo no pudiera estar presente, es decir participar físicamente - aun habiendo sido citado legalmente - ¿no podrán visionar, examinar las actas ? Si una parte o un testigo ha declarado judicialmente por medio de un exhorto, ¿no podrá la otra parte
} 
Na konieczność ogłoszenia akt, także w procesie skróconym, wskazują nie tylko przepisy kan. 1598 \$ 1 i 1620 nr 7 KPK oraz art. 231 DC, w których określono znaczenie publikacji akt i sprecyzowano skutki naruszenia przepisu de actorum publicatione. Na wspomnianą konieczność wskazuje też pośrednio kan. 1686 MIDI, gdzie ustawodawca wprost poleca instruktorowi wyznaczenie terminu piętnastu dni na dyskusję sprawy. Jest zrozumiałe, że strony mogą wziąć udział w tej dyskusji, a tym samym zgłosić stosowne wnioski obrończe ${ }^{81}$ i w pełni skorzystać z prawa do obrony, tylko wtedy, gdy znają całość materiału dowodowego. Sam fakt, że oboje przedstawili zgodne żądanie o orzeczenie nieważności małżeństwa, nie oznacza jeszcze, zwłaszcza w sytuacji, kiedy podczas posiedzenia dowodowego sądu nie mogli wziąć udziału w przesłuchaniu drugiej strony, świadków lub biegłych, że znają wszystkie dowody w sprawie. Innymi słowy, nie miałaby żadnego sensu dyskusja sprawy z udziałem stron procesowych, jeśli sędzia instruktor nie umożliwiłby im przejrzenia akt $^{82}$.

y el defensor del vínculo conocer dichas actas y proponer nuevas pruebas en base a los resultados instructorios ? Demasiado simplicista se nos presenta el procedimiento en el processus brevior en relación al principio de publicidad del mismo". M. V. Hernández Rodriguez, El processus matrimonialis brevior coram episcopo. Iustum iudicium?, Revista Universitas Canonica 33 (2016) s. 174-175.

${ }^{81} \mathrm{O}$ możliwości przedłożenia takich wniosków wprost traktuje ustawodawca, kiedy w kan. 1686 MIDI wyraźnie postanawia: „Instruktor, o ile to możliwe, winien zebrać dowody podczas jednego posiedzenia i wyznaczyć termin piętnastu dni na przedstawienie uwag na korzyść węzła oraz wniosków obrończych stron [podkreślenie - J.K.], jeżeli takie zgłaszają".

„Le canon 1686 CIC dit que le défenseur du lien et les parties, si elles le veulent, ont alors 15 jours pour présenter leurs observations ou plaidoiries. Ni le motu proprio, ni la Ratio ne parlent ici de l'avocat, ni de la discussion qui est prévue dans la procédure ordinaire, permettant au défenseur du lien et aux avocats des parties de réagir à leurs écritures respectives. Mais on peut supposer que dans le silence de ce texte plus spécial, les lois générales des procès ordinaires s'appliquent et qu'une discussion doit pouvoir être organisée". PH. Toxé, La réforme des procès en nullité de mariage selon le motu proprio Mitis Iudex Dominus Iesus, [art. cyt.], s. 123.

${ }^{82}$ Według Felipe Heredii Estebana, w procesie skróconym nie przewiduje się publikacji akt $\mathrm{z}$ powodu czynnego udziału stron $\mathrm{w}$ fazie wstępnej procesu i $\mathrm{w}$ sesji dowodowej, kiedy mają oni prawo brać udział w przesłuchaniach stron i świadków. 
Powoływanie się na fakt, że w kan. 1686 MIDI ustawodawca nie nadmienia wprost o ogłoszeniu akt, nie oznacza, że uchyla on tym samym wspomniany jakże istotny obowiązek, bez którego nie sposób mówić o przestrzeganiu prawa do obrony. W tym samym kanonie ustawodawca nie wspomina też o zamknięciu postępowania dowodowego w sprawie, kiedy postanawia jedynie o zebraniu dowodów, jeśli to możliwe, podczas jednego posiedzenia oraz wyznaczeniu terminu piętnastu dni na przedstawienie uwag na korzyść węzła małżeńskiego i wniosków obrończych stron. Nie podlega jednak dyskusji, że w myśl kan. 1601 KPK sędzia powinien wyznaczyć odpowiedni okres na przedstawienie wniosków obrończych lub uwag „po zamknięciu postępowania dowodowego". Innymi słowy, jak nie istnieją podstawy do twierdzenia, że w nader ogólnej normie, jaką określono w kan. 1686 MIDI, uchylono zamknięcie postępowania dowodowego w procesie skróconym, skoro ustawodawca wprost przewiduje tu dyskusję sprawy, tak samo nie ma tam żadnych oczywistych przesłanek, które dają podstawę do twierdzenia, że w tym samym procesie prawodawca odstąpił od publikacji akt ${ }^{83}$.

Zaraz jednak wspomniany sędzia Roty Rzymskiej stanowczo zastrzega: „Sin embargo, el derecho de defensa exige que sean publicadas las actas cuando se ha hecho uso de exhortos para obtener el testimonio de los testigos o de otras pruebas; nos encontraríamos en la misma situación si una o ambas partes no hubieran asistido a la sesión instructoria o la defensa del vínculo no hubiera estado presente. La celeridad del proceso debe ser siempre compatible con el derecho de defensa, que debe permanecer siempre integro [podkreślenie - J. K.]". F.H. EsteBAN, El proceso más breve ante el obispo, Anuario de Derecho Canónico 5 Supl. [Octobre 2016], s. 116.

${ }^{83}$ Podobnie, jak słusznie zauważa Luis De Ruschi, ustawodawca nie nadmienia o ustanowieniu w każdej sprawie o orzeczenie nieważności małżeństwa w procesie skróconym notariusza, chociaż wprost zaznacza on w MIDI, że „odpowiedzi stron i świadków powinny być zredagowane na piśmie przez notariusza" (art. $18 \$ 2$ ), a „wyrok [w takiej sprawie winien być - J.K.] podpisany przez biskupa i notariusza" (art. $20 \$ 2$ ). Zob. L. De Ruschi, El processus brevior del motu proprio Mitis Iudex Dominus Iesus. Una interpretación doctrinal, [art. cyt.], s. 220. Innymi słowy, jakkolwiek w kan. 1685 MIDI ustawodawca nie nadmienia ani słowem o ustanowieniu przez wikariusza sądowego notariusza, nie podlega dyskusji, że w każdym w procesie skróconym „powinien brać udział notariusz, tak że akta należy uznać za 
Ogłoszenie akt de facto nie musi wcale wpłynąć na przedłużenie czasu trwania procesu. Jeśli bowiem wszystkie dowody w sprawie udało się zebrać podczas posiedzenia, o jakim jest mowa w kan. 1685 i 1686 MIDI, publikacja akt może mieć miejsce w tym samym dniu, bezpośrednio po zakończeniu posiedzenia dowodowego sądu. Co więcej, bezpośrednio po zapoznaniu się z materiałem dowodowym strony jeszcze w tym samym dniu mogą odstąpić od złożenia takich wniosków ${ }^{84}$. Jeśli jednak - z powodu okoliczności czasu lub innych przyczyn - jest to niemożliwe, sędzia instruktor powinien dekretem pozwolić stronom i ich adwokatom, aby w kancelarii sądu przejrzeli przed dyskusją sprawy akta, które nie są im jeszcze znane ${ }^{85}$. Jest zrozumiałe, że w tym ostatnim przypadku instruktor winien zadbać, aby przejrzenie akt nastąpiło bez zbędnej zwłoki.

Jak zaznaczono wyżej, instruktor powinien tu pamiętać, że naruszenie przepisu o ogłoszeniu akt prowadzi do nieważności

nieważne, jeżeli nie zostały przez niego podpisane” (kan. $1437 \$ 1$ KPK). Podobnie rzecz się ma z publikacją akt. Choć ustawodawca wprost nie nadmienia o niej ani słowem, jej miejsce w procesie obrony jest tak zasadnicze, że odmowa ujawnienia akt, która - jak podkreślono wyżej - wcale nie musi niekorzystnie wpłynąć na czas trwania procesu sądowego, uniemożliwiłaby przeprowadzenie skutecznej obrony. ${ }^{84}$ Por. J. Ros CórColes, El vicario judicial y el instructor en los procesos de nulidad matrimonial tras el motu proprio Mitis Iudex, [art. cyt.], s. 100.

${ }^{85}$ Por. kan. $1598 \$ 1$ KPK; DC, art. $229 \$ 1-3$. Oczywiście, zgodnie z kan. $1598 \$ 1$ KPK, sędzia instruktor, dla uniknięcia bardzo poważnych niebezpieczeństw, może zdecydować, że jakiegoś aktu nie należy stronom ujawniać, gwarantując jednak, że prawo do obrony pozostaje zawsze nienaruszone. Por. DC, art. 230. W tym ostatnim przypadku instruktor winien jednak pamiętać o art. 234 DC, gdzie postanowiono: „Jeśli sędzia utrzymuje, że dla uniknięcia najbardziej poważnych niebezpieczeństw jakiegoś aktu nie należy ujawniać stronom, taki dokument może być przejrzany przez adwokatów stron, po uprzednim złożeniu przysięgi lub przyrzeczenia zachowania tajemnicy”. Por. kan. $1455 \S 3$ KPK.

Faktyczne niedopuszczenie do publikacji akt kłóciłoby się z fundamentalną funkcją adwokatów stron, których czynny udział w sprawach o orzeczenie nieważności małżeństwa w trybie skróconym przewiduje ustawodawca (zob. art. $18 \$ 1 \mathrm{MIDI}$ ). Odmowa ujawnienia akt po zebraniu dowodów przez sędziego instruktora oznaczałaby w tym przypadku pozbawienie ustanowionych przez strony procesowe adwokatów możliwości wykonania obowiązku obrony klienta. 
usuwalnej wyroku, w przypadku zaś faktycznego odmówienia stronom prawa do obrony, do nieważności nieusuwalnej orzeczenia biskupa diecezjalnego ${ }^{86}$.

Jeśli z dyskusji nie wyłoni się konieczność uzupełnienia materiału dowodowego, sędzia instruktor powinien natychmiast wydać dekret o zamknięciu instrukcji sprawy i „wyznaczyć termin piętnastu dni na przedstawienie uwag na korzyść węzła oraz wniosków obrończych stron"87. Zgodnie z art. 238 DC, instruktor winien powstrzymać się od wydania takiego dekretu, „jeśli uzna, że jest jeszcze coś do zbadania, aby sprawa mogła być uznana za wystarczająco wyjaśnioną". W tym ostatnim przypadku powinien nakazać uzupełnienie tego, czego brakuje.

\subsection{Przekazanie akt sprawy i konsultacja $\mathrm{z}$ biskupem diecezjalnym}

Z chwilą zakończenia dyskusji sędzia instruktor powinien jak najszybciej przekazać biskupowi diecezjalnemu wszystkie akta sprawy, wraz z opinią asesora. Do wspomnianych akt może on też dołączyć własną pisemną relację nt. wykonanego zadania ${ }^{88}$. Wprawdzie w MIDI nie ma nawet najmniejszej wzmianki o takiej relacji instruktora,

\footnotetext{
${ }^{86}$ Por. kan. 1598 § 1, 1620 nr 7 KPK; DC, art. 231. Jak słusznie zauważa Carmelo de Diego-Lora, „Odmowa ujawnienia akt przewidziana w tym kanonie [por. kan. 1598 \$ 1 in fine KPK - J.K.] stanowi wyjątek, który nie może przerodzić się w zasadę ogólną: «musi być całkiem jasne, że charakter publiczny procesu kanonicznego wobec stron nie narusza jego tajności wobec innych osób» (Jan Paweł II, Przemówienie do Roty Rzymskiej, 26 I 1989 r., nr 6 i 8)”. C. DE Diego-Lora, De actorum publicatione, de conclusione in causa et de causae discussione, w: Codex Iuris Canonici. Kodeks Prawa Kanonicznego. Komentarz. Edycja polska na podstawie wydania hiszpańskiego, red. nauk. P. Majer, Kraków 2011, s. 1199.

${ }^{87}$ Kan. 1686 MIDI.

${ }^{88}$ „Si bien el canon no lo prescribe, creemos que sería de gran ayuda para el Obispo Juez que el Instructor, previo a pasar las actas para su estudio, elabore una apta relatio, tal como está prevista en el canon $1704 \$ 1$ para el proceso de dispensa super rato. Se trata de un informe en el que el Instructor expone sintética y ordenadamente los argumentos de hecho y de derecho del caso, sin emitir opinión sobre lo alegado y probado, que es tarea exclusiva del Juez". L. DE Ruschi, El processus brevior del motu proprio Mitis Iudex Dominus Iesus. Una interpretación doctrinal, [art. cyt.],
} 
a jedynie dyspozycja o konsultacji biskupa diecezjalnego z instruktorem i asesorem ${ }^{89}$, biskup może poprosić sędziego instruktora o taką relację. Również sam instruktor, zwłaszcza w sytuacji, kiedy wdrożone postępowanie dowodowe ujawniło wiele zaskakujących zwrotów akcji, może z własnej inicjatywy - tytułem przedstawienia zwięzłej informacji nt. zaskarżonego małżeństwa, zachowania stron i czynności procesowych podjętych w sprawie - dołączyć do akt sprawy pisemną relację. Jest oczywiste, że wspomniana relacja instruktora nie może stanowić votum pro rei veritate. Sędzia instruktor nie wypowiada się bowiem na korzyść lub przeciwko stanowisku wyrażonemu w skardze powodowej. Jego bardzo zwięzła relacja powinna jedynie zawierać informacje o istotnych faktach dotyczących małżeństwa stron i przeprowadzonej instrukcji sprawy. Jako taka, bez wypowiadania się co do meritum sprawy, winna służyć biskupowi diecezjalnemu, jako jeden z pomocniczych środków, w wydaniu orzeczenia w procesie.

Naturalnie, biskup diecezjalny, który po otrzymaniu akt powinien skonsultować się w sprawie $\mathrm{z}$ instruktorem i asesorem, może poprzestać na samej tylko konsultacji ustnej ${ }^{90}$. W tej sytuacji sędzia

s. 223. Por. PH. Toxé, La réforme des procès en nullité de mariage selon le motu proprio Mitis Iudex Dominus Iesus, [art. cyt.], s. 124.

${ }^{89}$ Por. kan. $1687 \$ 1$ MIDI.

${ }^{90}$ Biskup diecezjalny, w przeciwieństwie do sędziego jednoosobowego w procesie o orzeczenie nieważności małżeństwa w trybie zwyczajnym (por. kan. $1425 \$ 4 \mathrm{KPK}$, kan.1673 \$ 4 MIDI), nie może odstąpić od wysłuchania tych dwóch członków trybunału (por. kan. $127 \$ \mathrm{KPK}$ ). O ile bowiem w sprawie o stwierdzenie nieważności małżeństwa w I instancji sędzia jednoosobowy, gdzie jest to możliwe, winien sobie dobrać asesora i audytora, de facto może zrezygnować z konsultacji z tymi dwoma członkami kolegium i wspomniane zaniechanie wysłuchania audytora i asesora, jak zauważa León del Amo, „nie powoduje nieważności czynności sędziego” (L. del Amo, De foro competenti, [w:] Codex Iuris Canonici. Kodeks Prawa Kanonicznego. Komentarz. Edycja polska na podstawie wydania hiszpańskiego, red. nauk. P. Majer, Kraków 2011, s. 1069), o tyle ustanowienie instruktora i asesora w procesie skróconym nie ma charakteru fakultatywnego, a tym samym biskup diecezjalny nie może nie skonsultować się z nimi. Innymi słowy, orzeczenie biskupa diecezjalnego w procesie skróconym wydane bez konsultacji z instruktorem i asesorem byłoby nieważne. Naturalnie, biskup diecezjalny, który jest jedynym sędzią w takim procesie, 
odpowiedzialny za przeprowadzenie instrukcji sprawy winien odnieść się do wszystkich kwestii przedłożonych mu przez biskupa, z wyłączeniem tych, które wprost dotyczą meritum sprawy.

\section{Zasady prawa, jakie powinien uszanować instruktor w procesie skróconym}

Sędzia instruktor w skróconym procesie małżeńskim nie może nie respektować zasad prawa kanonicznego, właściwych dla administrowania sprawiedliwości kanonicznej. Innymi słowy, podejmując czynności o charakterze procesowym powinien on mieć na względzie ogólne i specjalne zasady prawa kanonicznego, określone w prawie powszechnym i partykularnym, stosujące się do spraw o orzeczenie nieważności małżeństwa. Naturalnie, jeśli chodzi o zasady natury ogólnej, nie należy w sprawach o stwierdzenie nieważności małżeństwa w procesie skróconym stosować tych, które wprost i wyraźnie zostały uchylone przez najwyższego ustawodawcę, który dopuścił wspomniany tryb postępowania, i które same $z$ siebie są sprzeczne ze szczególną naturą procesu skróconego.

\subsection{Sam biskup jest sędzią w procesie skróconym}

W procesie skróconym jedynym sędzią, który może orzekać w sprawie - i to we wszelkich kwestiach - jest biskup diecezjalny. On w tych „przypadkach, w których skarga o nieważność małżeństwa jest poparta szczególnie oczywistymi argumentami”", jest „osobiście w swoim Kościele [...] sędzią wobec wiernych, którzy zostali mu powierzeni"92, i najwyższym gwarantem takiego sprawowania władzy sądowniczej, w którym „nie dojdzie do jakiejkolwiek formy

\footnotetext{
winien jedynie skonsultować się z tymi członkami trybunału a tym samym nie musi wydawać wyroku zgodnie z radą asesora. Nie musi tego czynić także w sytuacji, kiedy nie jest kanonistą.

${ }^{91}$ MIDI, IV.

${ }^{92}$ MIDI, III.
} 
laksyzmu" ${ }^{13}$ w zakresie zachowania dyscypliny kościelnej ${ }^{94}$. Wobec powyższego, sędzia instruktor, który pełni w takim postępowaniu jedynie zadania o charakterze pomocniczym, nie może sobie pozwolić na jakiekolwiek działania, które w istocie oznaczałyby uzurpację urzędu sędziego wyrokującego w sprawie ${ }^{95}$.

Przykładem takich działań mogą być następujące czynności procesowe: zmiana formuły wątpliwości ${ }^{96}$; przyjęcie dowodu w przypadku kwestii co do jego dopuszczenia ${ }^{97}$; odrzucenie środków dowodowych, które zdaniem przynajmniej jednej ze stron dotyczą sprawy, a wspomniana reiectio nie jest podyktowana formalnymi wymogami stosującymi się do kwalifikacji prawnych dowodów ${ }^{98}$; ocena co do faktów

${ }^{93}$ MIDI, II. Por. tamże, IV in fine.

${ }^{94}$ Naturalnie, zgodnie z przepisami prawa biskup diecezjalny może zasięgnąć w tym przypadku opinii asesora. Żadną miarą nie jest jednak związany jego stanowiskiem w sprawie.

${ }^{95}$ Jest oczywiste, że wspomniana uzurpacja urzędu sędziego wyrokującego w sprawie nie ma miejsca w sytuacji, kiedy biskup diecezjalny, po podjęciu decyzji $\mathrm{w}$ procesie, prosi instruktora o zredagowanie wyroku. Por. Le condizioni di ammissione al processo breve e il ruolo del vescovo in tale forma processuale. Prolusione di Paolo Bianchi all'inaugurazione anno giudiziario del Tribunale Ecclesiastico Interdiocesano Umbro, Perugia, 6 marzo 2018, http://www.arcidiocesitrani.it/ arcidiocesi/images/documenti/2018Fedeli-separati/38.Condizioni-Ammissione-Processo-Breve-Bianchi.pdf [dostęp: 1-07-2019].

${ }^{96}$ „Actualmente ¿xistiría esta posibilidad de modificar la fórmula de la duda? Y si fuera así, ¿tendría el instructor esta facultad en el proceso abreviado? Es decir, vistas las pruebas ¿podría el instructor modificar la fórmula de la duda? La respuesta va unida a la naturaleza jurídica de su función : como se ha visto más arriba, el instructor no tiene la función del juez, por lo que nuestra respuesta es que el instructor no puede modificar la fórmula de la duda, que es sólo competencia del juez (el obispo), quien es llamado a pronunciarse una vez finalizada la instrucción [...]”. G. NúÑ̃Ez, El proceso brevior: exigencias y estructura, [art. cyt.], s. 147-148.

${ }_{97}$ „Jeśli pojawi się kwestia w przedmiocie dopuszczenia dowodu, audytor - zgodnie $\mathrm{z}$ art. $50 \$ 3$ - może zadecydować jedynie tymczasowo”. DC, art. $158 \$ 2$.

${ }^{98}$ Innymi słowy, sędzia instruktor może odrzucić, o ile nie zostało to wprost zastrzeżone w zleceniu, te środki dowodowe, co do których nie ma wątpliwości, że są godziwe, autentyczne i pożyteczne do poznania sprawy (por. kan. 1527 \$ 1 KPK). W przypadku odrzucenia przez instruktora takiego dowodu zgłoszonego podczas jedynej sesji sądowej, stosowne odwołanie winno zostać dokonane przez stronę 
stwierdzonych przez jednego z procesujących się i przyjętych przez drugiego 99 ; ocena co do tego, czy przytaczane „okoliczności dotyczące faktów lub osób” są „poparte zeznaniami lub dokumentami, które nie wymagają przeprowadzenia dokładniejszego badania albo dochodzenia oraz w sposób oczywisty wskazują na nieważność"100 małżeństwa; rozpatrzenie sprawy wpadkowej ${ }^{101}$.

Jeśli mowa o uszanowaniu przez instruktora zasady „sam biskup jest sędzią”, może on - o ile jest to konieczne dla właściwego przeprowadzenia postępowania dowodowego - prosić biskupa diecezjalnego, i to na każdym stadium instrukcji sprawy, o rozstrzygnięcie poszczególnych pilnych kwestii. Bez wątpienia do takich kwestii nie należy zaliczyć tych, które wprost dotyczą sposobu zbierania dowodów, jasno określonego w zbiorach prawa powszechnego i przez jurysprudencję Roty Rzymskiej ${ }^{102}$.

\subsection{Sprawa o orzeczenie nieważności małżeństwa nie może być} rozpoznawana $\mathrm{w}$ drodze ustnego procesu spornego lub sumarycznego

Jakkolwiek procedura sądowa w procesie skróconym ma charakter uproszczony, co więcej niektóre z czynności procesowych także te obejmujące instrukcję sprawy - są realizowane w sposób

jeszcze podczas wspomnianej sesji i natychmiast rozstrzygnięte. Co więcej, jak zauważa, Gerardo Núñez, od tej decyzji instruktora nie można już się odwołać ( $E l$ proceso brevior: exigencias y estructura, art. cyt., s. 150). Jeśli zaś chodzi o wszelkie wątpliwości dotyczące charakteru zgłoszonych dowodów i ich znaczenia prawnego, rozstrzyga je biskup diecezjalny, który jest jedynym sędzią w takim procesie.

${ }^{99}$ Por. kan. $1526 \S 2$ nr 2 KPK.

${ }^{100}$ Kan. 1683 nr 2 MIDI.

${ }^{101}$ Por. DC, art. 227.

${ }^{102}$ Jak wiadomo, te ostatnie zasady procesowe, sformułowane przez sędziów Roty Rzymskiej, mają charakter wiążący wobec sędziów niższego stopnia. Wynika to z dyspozycji kan. $19 \mathrm{KPK}$, gdzie wyraźnie postanowiono: „Jeśli w określonej sprawie brak wyraźnej ustawy, powszechnej lub partykularnej, albo prawa zwyczajowego, sprawa - z wyjątkiem karnej - winna być rozstrzygnięta z uwzględnieniem ustaw wydanych w podobnych sprawach, ogólnych zasad prawnych z zachowaniem słuszności kanonicznej, jurysprudencji, praktyki Kurii Rzymskiej oraz powszechnej i stałej opinii uczonych". 
charakterystyczny dla ustnego procesu spornego ${ }^{103}$, żadną miarą sędzia instruktor nie może stosować w tym przypadku zasad sumarycznego procesu ustnego ${ }^{104}$. Instruktor nie może tego uczynić tym bardziej, że najwyższy ustawodawca wprost wyklucza możliwość rozpatrzenia sprawy o stwierdzenie nieważności małżeństwa w drodze ustnego procesu spornego. W kan. 1690 KPK wyraźnie zastrzeżono: „Causae ad matrimonii nullitatem declarandam nequeunt procesu contentioso orali tractari”. Tak samo Papież Franciszek zastrzega, iż sprawy, które dotyczą orzeczenia nieważności małżeństwa, nie mogą być rozpatrywane $\mathrm{w}$ drodze ustnego procesu spornego, o którym jest mowa w kan. 1656-1670 KPK ${ }^{105}$. Innymi słowy, gdyby sędzia instruktor wdrożył w ramach postępowania dowodowego zasady ustnego

\footnotetext{
${ }^{103}$ Por. M. Greszata-Telusiewicz, Processus brevior, w: Proces małżeński według motu proprio Mitis Iudex Dominus Iesus, red. J. Krajczyński, Płock 2015, s. 75-92. ${ }^{104}$ Jakkolwiek wiele osób domagało się od Biskupa Rzymskiego wdrożenia, zwłaszcza w przypadkach, kiedy nieważność małżeństwa zdaje się jawić jako oczywista, procesu sumarycznego, Papież Franciszek nie przychylił się do tych postulatów. Proces małżeński skrócony wobec biskupa diecezjalnego, którego zasady ustalono w MIDI, nie ma nic wspólnego z pobieżnością postępowania sądowego, pobłażliwością dla fundamentalnych zasad sprawiedliwości kanonicznej, niedokładnym, powierzchownym i pośpiesznym badaniem faktów i okoliczności dotyczących sprawy o orzeczenie nieważności małżeństwa. Jak podkreśla P. Malecha z Najwyższego Trybunały Sygnatury Apostolskiej, „Procedura sumaryczna miała dotąd zastosowanie tylko w ustnym procesie spornym (zob. kann. 1656-1670 KPK i kann. 1343-1356 KKKW), przy czym za pośrednictwem tego procesu nie mogły być rozpatrywane sprawy dotyczące orzeczenia nieważności małżeństwa (por. kann. 1690 KPK i $1375 \mathrm{KKKW}$ ). Podobnie stanowi nowe prawo (por. nowe kann. $1691 \$ 2$ KPK i $1377 \$ 2$ ). Wynika z tego jasno, że procedura sumaryczna nie została zaakceptowana przez Papieża Franciszka. Proces zaś małżeński skrócony przed biskupem (processus matrimonialis brevior coram Episcopo), mimo wielu podobieństw, nie jest procesem sumarycznym". P. MALECHA, Gwarancja sprawiedliwości oraz reforma procesu małżeńskiego widziana przez pryzmat konieczności jego przyśpieszenia i ułatwienia wiernym kontaktu z trybunałem; przygotowanie pracowników i odpowiedzialność biskupa, s. 170.

${ }^{105}$ Zob. kan. $1691 \S 2$ MIDI.
} 
procesu spornego niedopuszczone przez prawo, akta sądowe byłyby nieważne ${ }^{106}$.

Jako przykład działań właściwych dla ustnego procesu spornego, których sędzia instruktor nie może dopuścić w ramach postępowania dowodowego w sprawie o orzeczenie nieważności małżeństwa w procesie skróconym, należy wymienić następujące: wykluczenie możliwości przedstawienia dowodów przed lub po posiedzeniu sądu, o jakim jest mowa w kan. 1685 i 1686 MIDI $^{107}$; ustna dyskusja sprawy wobec trybunału, zamiast wymiany uwag na piśmie ${ }^{108}$.

\subsection{Postępowanie nie tylko na wniosek stron, ale także z urzędu}

Sprawy o orzeczenie nieważności małżeństwa prowadzone w trybie skróconym dotyczą najistotniejszych wartości chronionych przez prawo kanoniczne, mianowicie dobra publicznego Kościoła oraz zbawienia dusz ${ }^{109}$. Jeśli zatem strony procesowe, na przykład z powodu ignorancji lub opieszałości, zaniedbują swoje obowiązki w zakresie przedkładania dowodów lub składania zarzutów, sędzia instruktor - ilekroć uzna to za konieczne dla uniknięcia niesprawiedliwego wyroku - powinien $\mathrm{z}$ urzędu podjąć stosowne działania mające na celu uzupełnienie zaniedbań stron ${ }^{110}$.

\footnotetext{
${ }^{106}$ Por. kan. $1656 \S 2$ KPK.

${ }^{107} \mathrm{~W}$ przypadku zbierania dowodów w procesie skróconym są możliwe wyjątki od zasady koncentracji. Inaczej, dowody w sprawie można przedstawiać także poza posiedzeniem sądu, podczas którego - jak zaznaczono w kan. 1686 MIDI - „instruktor, o ile to możliwe, winien zebrać dowody”. Dowody te można przedkładać wcześniej (zob. kan. 1529 KPK), zwłaszcza gdy istnieje niebezpieczeństwo ich utraty, jak później, czyli po zakończeniu posiedzenia sądu, o którym w kan. 1685 i 1686 MIDI, a przed dyskusją sprawy.

${ }^{108}$ Por. kan. $1602 \$ 1$ KPK; DC, art. $244 \$ 1$.

${ }^{109}$ Por. kan. $1452 \$ 1$ KPK.

${ }^{110}$ Zob. kan. $1452 \S 1-2$ KPK; DC, art. $71 \S 1$. „Si bien la norma no lo indica, el Instructor podrá suplir la negligencia de las partes y ordenar pruebas de oficio para evitar una sentencia gravemente injusta, salvada la presunción del validez del vínculo matrimonial”. L. DE Ruschi, El processus brevior del motu proprio Mitis Iudex Dominus Iesus. Una interpretación doctrinal, [art. cyt.], s. 221.
} 
Tytułem przykładu można tu wskazać następujące czynności procesowe, jakie w imię służby prawdzie powinien ex officio podjąć sędzia instruktor delegowany do przeprowadzenia postępowania dowodowego w sprawie o orzeczenie nieważności małżeństwa w procesie skróconym: ustanowienie kuratora w przypadku stron dotkniętych zaburzeniami psychicznymi ${ }^{111}$; powołanie biegłego, ilekroć uzna za konieczne jego przesłuchanie lub opinię $e^{112}$; stwierdzenie wad, które mogą spowodować nieważność wyroku ${ }^{113}$.

3.4. Troska o zachowanie formalnych wymogów dotyczących instrukcji sprawy

Instruktor odpowiedzialny za przeprowadzenie postępowania dowodowego w procesie o orzeczenie nieważności małżeństwa w trybie skróconym powinien dopilnować, aby została potwierdzona autentyczność i integralność wszystkich zebranych środków dowodowych $^{114}$. Świadom tego, że żądanie w prowadzonym procesie „zostało zgłoszone przez obydwoje małżonków lub przez jednego z nich za zgodą drugiego" 115 , powinien zarazem zadbać, aby w zbieraniu dowodów uniknąć jakiegokolwiek oszustwa lub zmowy ${ }^{116}$. Wreszcie, nie wolno mu zapomnieć o szczególnym charakterze tego postępowania sądowego. Innymi słowy, sędzia instruktor winien mieć baczenie, by proces zakończył się $\mathrm{w}$ terminie przewidzianym przez ustawodawcę. Aby zachować ostatni z wymienionych warunków, posiada on prawo ograniczenia zbyt dużej liczby świadków i innych dowodów oraz niedopuszczenia środków dowodowych, które zostały przedłożone w celu przedłużania procesu ${ }^{117}$.

\footnotetext{
${ }^{111}$ Por. kan. $1478 \$ 4$ KPK.

${ }^{112}$ Por. kan. 1574 KPK.

${ }^{113}$ Por. kan. $1459 \$ 1$ KPK.

114 Por. DC, art. $161 \$ 2$.

${ }^{115}$ Kan. 1683 nr 1 MIDI.

${ }^{116}$ Por. DC, art. $161 \S 2$.

${ }^{117}$ Por. kan. 1553 KPK; DC, art. $157 \S 3$.
} 


\subsection{Posługa w duchu zasad prawa: favor matrimonii i favor} indissolubilitatis, nie zaś favor libertatis lub favor personae

Ponieważ wikariusz sądowy, jeszcze przed przyjęciem sprawy, „winien mieć pewność, że małżeństwo rozpadło się w sposób nieodwracalny, tak iż nie ma możliwości wznowienia wspólnoty życia małżeńskiego" ${ }^{118}$, wszelkie działania o charakterze procesowym także te, które podejmuje sędzia instruktor - powinny mieć na celu tylko jedno, mianowicie: ustalenie faktów dotyczących zasadności przedłożonego roszczenia. Innymi słowy, pamiętając o uchyleniu przez Papieża Franciszka kan. 1676 KPK o konieczności przedsięwzięcia na każdym stadium procesu działań, które mają na celu doprowadzenie stron do wznowienia wspólnego życia, instruktor winien mieć na względzie wyłącznie następujące dwie zasady prawa: „favor matrimonii" i "favor indissolubilitatis" ${ }^{119}$. Sędzia instruktor świadom wreszcie tego, że mogą istnieć „okoliczności dotyczące faktów lub

\footnotetext{
${ }^{118}$ Kan. 1675 MIDI.

119 „Interpretacja i stosowanie norm KPK, o ile mają być realizowane w perspek-
} tywie teologicznej, muszą liczyć się z zasadami określonymi przez samego prawodawcę. W przypadku wykładni i stosowania prawa dotyczącego zgody małżeńskiej, dokonywanych przez wykonawców sprawiedliwości kanonicznej, należy między innymi bezwzględnie uszanować zasadę favor matrimonii. Innymi słowy, każdy wyrok lub dekret o ważności lub nieważności małżeństwa winien być wydany i wprowadzony w życie w kontekście eklezjalnym, który jest całkowicie przychylny nierozerwalnemu małżeństwu i opartej na nim rodzinie.

Favor iuris, którym cieszy się małżeństwo we wspólnocie Kościoła, zakłada domniemanie jego ważności, dopóki nie udowodni się czegoś przeciwnego. Inaczej, to co zewnętrznie jawi się jako dokonane poprawnie, w myśl prawa zasługuje na wstępne domniemanie ważności i w konsekwencji - na ochronę prawną. Tym samym, wszyscy ci, którzy rozpoznają i rozstrzygają czy dane małżeństwo zostało zawarte nieważnie i czy nadal takim pozostaje, nie mogą pominąć przychylności prawa, jaką cieszy się małżeństwo kanoniczne oraz związanej z nią presumpcji ważności w przypadku wątpliwości, wprowadzonej przez kan. $1060 \mathrm{KPK}$.

W praktyce, w przypadku spraw o orzeczenie nieważności małżeństwa $z$ tytułu braku lub wady zgody małżeńskiej, kierowanie się zasadą favor matrimonii winno oznaczać między innymi: kategoryczne odrzucenie tezy, według której miejsce favor matrimonii powinien zająć favor personae, favor veritatis subiecti czy favor libertatis [...]. 
osób”, które „w sposób oczywisty wskazują na nieważność [małżeństwa - J.K.]”"120, nie może zarazem zapomnieć, że „forma procesu skróconego” została ustanowiona wyłącznie „do zastosowania w przypadkach, w których skarga o nieważność małżeństwa jest poparta szczególnie oczywistymi argumentami"121, a tym samym nie należy realizować instrukcji sprawy w tego typu postępowaniu w duchu takich zasad, jak "favor libertatis", "favor personae" lub "favor veritatis subiecti"122.

Wierne przestrzeganie przez wykonawców sprawiedliwości kanonicznej zasady favor indissolubilitatis, która inspiruje całe prawo małżeńskie, tak materialne jak procesowe, służy ochronie samej instytucji małżeństwa. Zasada, która nie oznacza uprzedzenia do słusznych orzeczeń nieważności, wyraża rzeczywiste przekonanie o dobru, jakie wchodzi w grę w procesach o orzeczenie nieważności małżeństwa. U podstaw wspomnianej troski o małżeństwo nie leży mniej lub bardziej arbitralna decyzja prawodawcy, ale uznanie wartości tego obiektywnego i fundamentalnego dobra, jakim jest każdy związek małżeński i każda rodzina.

Kierowanie się zasadą favor matrimonii, stanowiącą jeden z elementów prawa kanonicznego, którego rolą jest między innymi ochrona praw osobistych wiernych, służy zarazem zabezpieczeniu praw małżonków". J. KRAJCZYŃsKI, Interpretacja i stosowanie norm dotyczacych zgody małżeńskiej w perspektywie teologicznej, w: J. Krajczyński (red.), Podmiotowość osoby ludzkiej i konsens małżeński, Płock 2005, s. 68-70.

${ }^{120}$ Kan. 1683 nr 2 MIDI.

${ }^{121}$ MIDI, IV.

${ }^{122}$ Por. J. Krajczyński, Orzekanie w sprawach o nieważność małżeństwa a dobro wspólne, w: Kościoły i inne związki wyznaniowe w służbie dobru wspólnemu. Pod red. W. Uruszczaka, K. Krzysztofek, M. Mikuły, Kraków 2014, s. 197-202; M. DEL Pozzo, Il processo matrimoniale più breve davanti al vescovo, Roma 2016, s. 183-185. Należy tu pamiętać, że wspomniane ryzyko postąpienia przez instruktora zgodnie z zasadą "favor veritatis subiecti” wyraźnie wzrasta wraz z rewolucyjną zmianą dyscypliny kanonicznej dotyczącej znaczenia dowodowego przyznania sadowego i oświadczenia stron, dokonaną przez Papieża Franciszka w kan. 1678 \$ 1 MIDI. Zgodnie z nową regulacją: „W sprawach o nieważność małżeństwa przyznanie się sądowe oraz oświadczenia stron, poparte ewentualnymi zeznaniami świadków potwierdzającymi ich wiarygodność, mogą mieć pełną wartość dowodową, którą winien ocenić sędzia, po dokładnym rozważeniu wszystkich wskazówek i poszlak, chyba że pojawią się inne elementy, które je obalają". Na wspomniane niebezpieczeństwo zwraca m.in. uwagę Patrick Hubert, wikariusz sądowy z Luksemburga. 
Poszanowanie przez instruktora wyżej wymienionych zasad prawa powinno być między innymi podyktowane tym, co tak wyraźnie eksponuje Papież Franciszek, który nie przychylił się do postulatów o wdrożenie w sprawach o stwierdzenie nieważności małżeństwa procesu administracyjnego. Oto wspomniana fundamentalna racja przywołana przez Biskupa Rzymu, która potwierdza zasadność bezwzględnego uszanowania zasady "favor matrimonii" i "favor indissolubilitatis”: „konieczność zagwarantowania w najwyższym stopniu ochrony prawdy świętego węzła"123.

\section{Zakończenie}

Reforma przepisów prawa stosujących się do procesu o orzeczenie nieważności małżeństwa, dokonana przez Papieża Franciszka, w tym ustanowienie procesu skróconego, w którym zbieranie dowodów zlecono sędziemu instruktorowi, bez wątpienia posiada istotne znaczenie eklezjalne. O ile sam processus brevior można określić jako autentycznie nowatorski i „oczekiwany” przez wiernych, o tyle dyspozycję

Stwierdza on m.in.: „On pourrait se demander si le nouveau can. 1678, \$1 n'ouvre pas la porte $a$ un tel favor veritatis subiecti. Tous ceux qui travaillent dans un tribunal d'Église savent bien qu'il n'y a pas seulement le danger de la malhonnêteté, mais aussi celui de la mauvaise mémoire et de la vérité tout à fait subjective.

Il y a donc un réel danger pour le juge-instructeur de ne pas chercher d'autres moyens de preuve éventuellement contraires à la confession où à la déclaration ! Il faut souligner le fait que la confession ou la déclaration des parties ne peut acquérir la force probante plénière que dans la deuxième étape de l’appréciation des preuves par le collège des juges, le juge unique ou l'évêque-juge. La force probante plénière ne peut pas déjà être attribuée pendant la phase d'instruction, guidée par le juge-instucteur dans le procès ordinaire, ni pendant la session d'instruction par l'instructeur dans le procès plus bref (nouveau can. 1686), et encore moins pendant l'enquête pastorale préliminaire prévue par les articles 2-4 des Règles de procédure !” P. HuBERT, «Ad certitudinem moralem iure necessariam...». La question des preuves à la lumière de motu proprio Mitis Iudex Dominus Iesus, [art. cyt.], s. 116-117.

${ }^{123}$ MIDI, Wstęp. Por. R. Minner ath, Les références doctrinales dans le motu proprio Mitids Iudex Dominus Iesus, Revue de Droit Canonique 67 (2017) 1, s. 105-106; P. HuBERT, «Ad certitudinem moralem iure necessariam...». La question des preuves à la lumière de motu proprio Mitis Iudex Dominus Iesus, [art. cyt.], s. 107-119. 
prawną o udziale instruktora w kolejnym procesie małżeńskim należy uznać za znaczne poszerzenie kompetencji tego sędziego delegowanego. Innymi słowy, choć charakter posługi sędziego instruktora w procesie kanonicznym był już wcześniej jasno określony, reforma prawa kanonicznego dokonana przez Franciszka wyraźnie poszerzyła katalog jego praw i obowiązków.

Próba określenia kompetencji tego sędziego w procesie skróconym pozwala stwierdzić, iż spełnia on w tym przypadku aktywną i nader odpowiedzialną funkcję. Charakter jego posługi, jakkolwiek zdeterminowany treścią zlecenia, jest bardzo dynamiczny i dość szeroki. Choć zadania sędziego instruktora ograniczone są w istocie do pomocy w zakresie postępowania dowodowego, jego posługa w pewnej mierze implikuje dalsze losy sprawy. Od zaangażowania instruktora, tempa jego pracy i skrupulatności w przestrzeganiu zasad procesowych w istocie zależy kształt decyzji biskupa diecezjalnego, który jest jedynym sędzią w procesie skróconym.

Zasady prawa dotyczące kompetencji sędziego instruktora w sprawach o orzeczenie nieważności małżeństwa w procesie skróconym niewątpliwie służą ochronie małżeństwa i rodziny. Można je określić jako słuszne i potrzebne. Niestety, wspomniane zasady prawa kanonicznego - zapewne przygotowane $\mathrm{w}$ pewnym pośpiechu - nie są wyczerpujące, zupełne, w pełni jasne i ewidentne. Wątpliwości budzi tu nade wszystko treść kan. 1686 MIDI, gdzie nader lapidarne sformułowanie normy prawa sprawia, że mogą powstawać dyskusje co do kształtu przebiegu postępowania dowodowego w procesie skróconym. 


\section{Competence of Judge-Instructor in processus brevior}

The author of the article clarifies briefly some specific obligations and rights of the Instructor, and recalls legal rules the Instructor needs to abide by during Abbreviated Judicial Process.

SŁowa KLUCzowe: Proces o orzeczenie nieważności małżeństwa; proces sądowy; proces skrócony; instruktor; obowiązki i prawa; nierozerwalność małżeństwa

Keywords: The Declaration of Nullity Process; the Judicial Process; the Abbreviated Process; the Instructor; the Obligations and Rights; the Indissolubility of Marriage

\section{NOTKA O AUTORZE:}

Ks. DR hab. Jan KrajCZyŃSki, PROF. UKSW - pracownik naukowo-dydaktyczny Wydziału Prawa Kanonicznego UKSW Warszawie, kierownik Zakładu Prawa o Posłudze Nauczania. 